\title{
Synthesis of Caged Nucleosides with Photoremovable Protecting Groups Linked to Intramolecular Antennae
}

\author{
by Joulia Smirnova, Dominik Wöll, Wolfgang Pfleiderer, and Ulrich E. Steiner* \\ Fachbereich Chemie, Universität Konstanz, Postfach 5560, D-78457 Konstanz \\ (e-mail: ulrich.steiner@uni-konstanz.de)
}

Based on the [2-(2-nitrophenyl)propoxy]carbonyl (nppoc) group, six new photolabile protecting groups (2, $\mathbf{8}, \mathbf{9 b}, \mathbf{1 6 b}, \mathbf{2 5 b}$, and 26), each covalently linked to a $9 H$-thioxanthen-9-one (Tx) unit functioning as an intramolecular triplet sensitizer, were synthesized. Linkers were introduced between the Me group or the aromatic ring of nppoc and the 2-position of Tx by means of classical organic synthesis combined with $\mathrm{Pd}$ catalyzed $\mathrm{C}-\mathrm{C}$ coupling reactions. The new photolabile protecting groups to be used in light-directed synthesis of DNA chips were attached to the $5^{\prime}$-O-atom of thymidine via a carbonate linkage, giving rise to the caged nucleosides 7, 11, 13, 19, 20, and 30 .

Introduction. - Light-directed, massive parallel combinatorial synthesis with photoremovable protecting groups allows the fabrication of high-density DNA chips [1][2], i.e., arrays of up to 1 million spots of different oligonucleotides on an area of $c a$. $1 \mathrm{~cm}^{2}$. Such high-density DNA chips represent highly effective diagnostic tools for a variety of genomic applications such as genotyping [3], gene-expression profiling [4], and sequencing by hybridization [5]. Several reviews on DNA chips and their application have been published [6-12].

The efficiency of the photolithographic technique for producing high-density DNA chips critically depends on the performance, i.e., the light sensitivity and the uniformity of the photochemical cleavage reaction of the photolabile protecting groups blocking either the terminal 5'-OH or the 3'-OH group in the growing oligonucleotides. Among the photolabile protecting groups currently in use for photolithographic DNA-chip synthesis [13], the [2-(2-nitrophenyl)propoxy]carbonyl (nppoc) group (1) developed by Pfleiderer and co-workers is a prominent example [14][15]. It reacts in excellent yield and gives rise to a good quantum yield, the only draw-back for a higher light sensitivity being its low absorption coefficient in the near UV, where illumination is usually performed with the $366-\mathrm{nm} \mathrm{Hg}$ line. It has been shown that this problem can be overcome by triplet sensitization, e.g., with $9 H$-thioxanthen-9-one ('thioxanthone'), which has a high absorption coefficient at $366 \mathrm{~nm}$ and, on diffusional encounters, transfers its triplet energy to the photoreactive nitrobenzyl chromophore [16]. In $\mathrm{O}_{2}$ free solution, the rate of photodeprotection of nppoc-protected thymidine is enhanced by a factor of $c a$. ten, when thioxanthone is added as a sensitizer. However, since intermolecular energy transfer is rate-limited by diffusion, in the presence of $\mathrm{O}_{2}$, the sensitizer is mostly quenched, and the enhancement of the photoreactivity is only weak or even absent. To avoid the diffusional step in energy transfer, we synthesized new 
protecting groups that utilize the sensitization principle, but with intramolecular energy transfer from a covalently linked sensitizer group to the photoreactive chromophore.<smiles>CC(=O)OCC(C)c1ccccc1[N+](=O)[O-]</smiles>

1

The structure of nppoc (1) allows the attachment of a thioxanthone (Tx) moiety to the aliphatic chain of the protecting group, or directly to the aromatic ring. In this paper we present strategies for the synthesis of several intramolecularly sensitized protecting groups, as well as the synthesis of $5^{\prime}$ - $O$-caged thymidines derived from them. The photochemical and photophysical properties of these new protecting groups will be published elsewhere.

Results and Discussion. - 1. Linkage of the Thioxanthone Moiety to the Aliphatic Chain of nррос. In linking the sensitizer to the photolabile protecting group, we tried to avoid adverse effects on the reactivity of the photoreactive group that might result from the structural change associated with the substitution of the linker. It has been established that the primary photoreaction of nppoc consists in an intramolecular $\mathrm{H}$ atom transfer from the benzylic $\mathrm{CH}$ to the $\mathrm{NO}_{2}$ group. Hence, the $\mathrm{H}$-acceptor ability of the photo-excited $\mathrm{NO}_{2}$ group and the $\mathrm{H}$-donor ability of the benzylic $\mathrm{CH}$ group are relevant. Connecting the linker to the Me group of nppoc should neither have significant effect on the electronic system involved in the photoactive $n \pi^{*}$-state, nor should the extension of the side chain at the benzylic $\mathrm{C}$-atom by another saturated $\mathrm{C}-\mathrm{C}$ unit substantially reduce the $\mathrm{H}$-donor activity of the benzylic $\mathrm{C}-\mathrm{H}$ bond. Three $\mathrm{C}_{3}$ linkages (propyne-1,3-diyl, propene-1,3-diyl, and propane-1,3-diyl) and one $\mathrm{C}_{2}$ linkage (ethane-1,2-diyl) were realized in this work.

Our approach to the protecting group with a triple bond in the aliphatic $\mathrm{C}_{3}$ linkage between the basic nppoc group 1 and the Tx residue is shown in Scheme 1. The synthesis of 2 started with the alkylation of methyl 2-nitrophenylacetate (3) with propargyl bromide in the presence of $t$-BuOK to give the pent-4-ynoate 4 in $48 \%$ yield. Reduction of 4 with $\mathrm{NaBH}_{4}$ following the method of Soai and co-workers [17] proceeded smoothly, and allowed us to obtain the alcohol $\mathbf{5}$ in $78 \%$ yield. Coupling of $\mathbf{5}$ with 2bromo-9H-thioxanthen-9-one (6) under classical Sonogashira conditions [18] provided the desired protecting group $\mathbf{2}$ in $31 \%$ yield.

The caged thymidine $\mathbf{7}$ was derived from $\mathbf{2}$ according to [14]. Compound $\mathbf{2}$ was treated with phosgene, and the resulting chloroformate was allowed to react with thymidine, which afforded the 5'-O-protected derivative 7. The overall yield of the reaction was quite low $(15 \%)$ due to some side reactions.

For the synthesis of the protecting groups $\mathbf{8}$ and $\mathbf{9 b}$ with $\mathrm{C}=\mathrm{C}$ and $\mathrm{C}-\mathrm{C}$ bonds, respectively, in the $\mathrm{C}_{3}$ linkage, we developed a synthetic strategy that allowed us to use the same precursor $\mathbf{1 0}$ for the synthesis of both compounds (Scheme 2). The key step to the protected thymidine 11, bearing a $\mathrm{C}=\mathrm{C}$ bond in the Tx-based linkage, was a Heck reaction of the allylic alcohol $\mathbf{1 0}$ with 2 -iodo-9H-thioxanthen-9-one (12) [19] [20]. For the analogue 13, a hydroboration-Suzuki coupling sequence between the same 


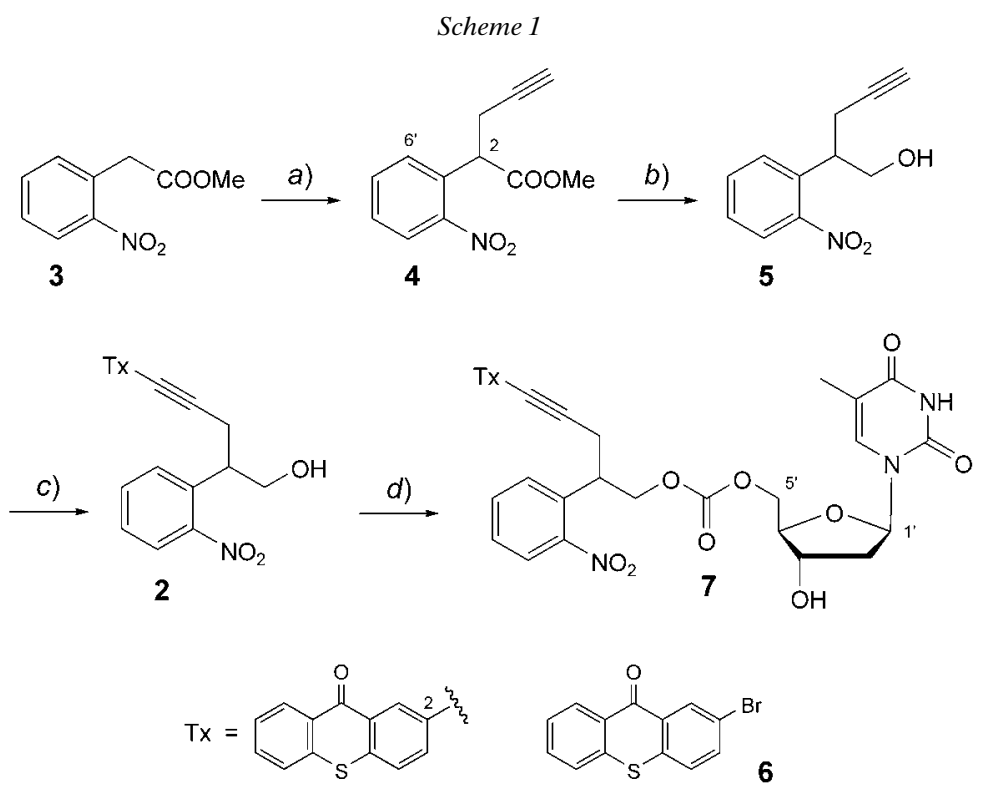

a) $t$-BuOK, $\mathrm{HC} \equiv \mathrm{CCH}_{2} \mathrm{Br}, \mathrm{THF} ;-80^{\circ} \rightarrow$ r.t., $12 \mathrm{~h} ; 48 \%$. b) $\mathrm{NaBH}_{4}, t$-BuOH, $\mathrm{MeOH}, 80^{\circ}, 4 \mathrm{~h} ; 78 \%$. c) 1 . CuI, $\left[\mathrm{Pd}\left(\mathrm{PPh}_{3}\right)_{4}\right], \mathrm{Et}_{3} \mathrm{~N}, \mathrm{THF} ; 2.5$, r.t., $20 \mathrm{~h} ; 31 \%$. d) 1. $20 \%$ soln. of phosgene in toluene, THF, r.t., 14 h; 2. thymidine, pyridine, $\mathrm{CH}_{2} \mathrm{Cl}_{2},-40^{\circ} \rightarrow 0^{\circ}, 4 \mathrm{~h}$, r.t. $48 \mathrm{~h} ; 15 \%$.

starting compounds was the main step. Precursor 10 was prepared in $93 \%$ yield by reduction of the ester $\mathbf{1 4}$ [21] with $\mathrm{NaBH}_{4}$ in $\mathrm{THF} / \mathrm{MeOH}$ [22] (initial attempts to use $t$ $\mathrm{BuOH} / \mathrm{MeOH}$, analogous to $\mathbf{4} \rightarrow \mathbf{5}$, led to $\mathbf{1 0}$ in less then $20 \%$ yield). The Heck reaction [23] [24] between $\mathbf{1 0}$ and $\mathbf{1 2}$ in the presence of a catalytic amount of [ $\left.\mathrm{Pd}(\mathrm{OAc})_{2}\right], \mathrm{Bu}_{3} \mathrm{P}$, and $\mathrm{K}_{2} \mathrm{CO}_{3}$ in DMF afforded the adduct 8 in $24 \%$ yield. Several attempts have been made at improving the yield of the Heck coupling reaction, but any variations in the catalytic system, solvents, and reaction time [23-25] did not increase the yield. The Heck coupling product $\mathbf{8}$ was also prepared from the silyl-protected alcohol 15, made from 14, employing the same conditions as for the unprotected form 10 [26][27]. Deblocking of the $\mathrm{OH}$ group of $\mathbf{1 5}$ with $\mathrm{Bu}_{4} \mathrm{NF}$ in THF [26] gave the alcohol $\mathbf{8}$ in an overall yield of $42 \%$ from 10. The caged thymidine $\mathbf{1 1}$ was finally derived from $\mathbf{8}$ by treatment with phosgene, and reaction of the chloroformate with thymidine $(34 \%$ yield) [14].

For the synthesis of $\mathbf{1 3}$, the silyl ether $\mathbf{1 5}$ was subjected to hydroboration with 9BBN (=9-borabicyclo[3.3.1]nonane), followed by Suzuki coupling [28][29] with 2bromothioxanthone 6 in the presence of [1,1'-bis(diphenylphosphino)ferrocene]dichloropalladium(II) $\left(\left[\mathrm{Pd}(\mathrm{dppf}) \mathrm{Cl}_{2}\right]\right)$ and $3 \mathrm{M}$ aq. $\mathrm{K}_{3} \mathrm{PO}_{4}$ to afford the silyl-protected alcohol 9a. Deprotection of the $t-\mathrm{BuMe}_{2} \mathrm{Si}$ group [26] led to the free alcohol $9 \mathbf{b}$ in $47 \%$ yield (two steps). Treatment of $\mathbf{9 b}$ with trichloromethyl chloroformate (diphosgene) in the presence of $\mathrm{Et}_{3} \mathrm{~N}$ [14][30][31], followed by reaction of the resulting chloroformate with thymidine, resulted in the formation of $\mathbf{1 3}$ in $58 \%$ yield. 


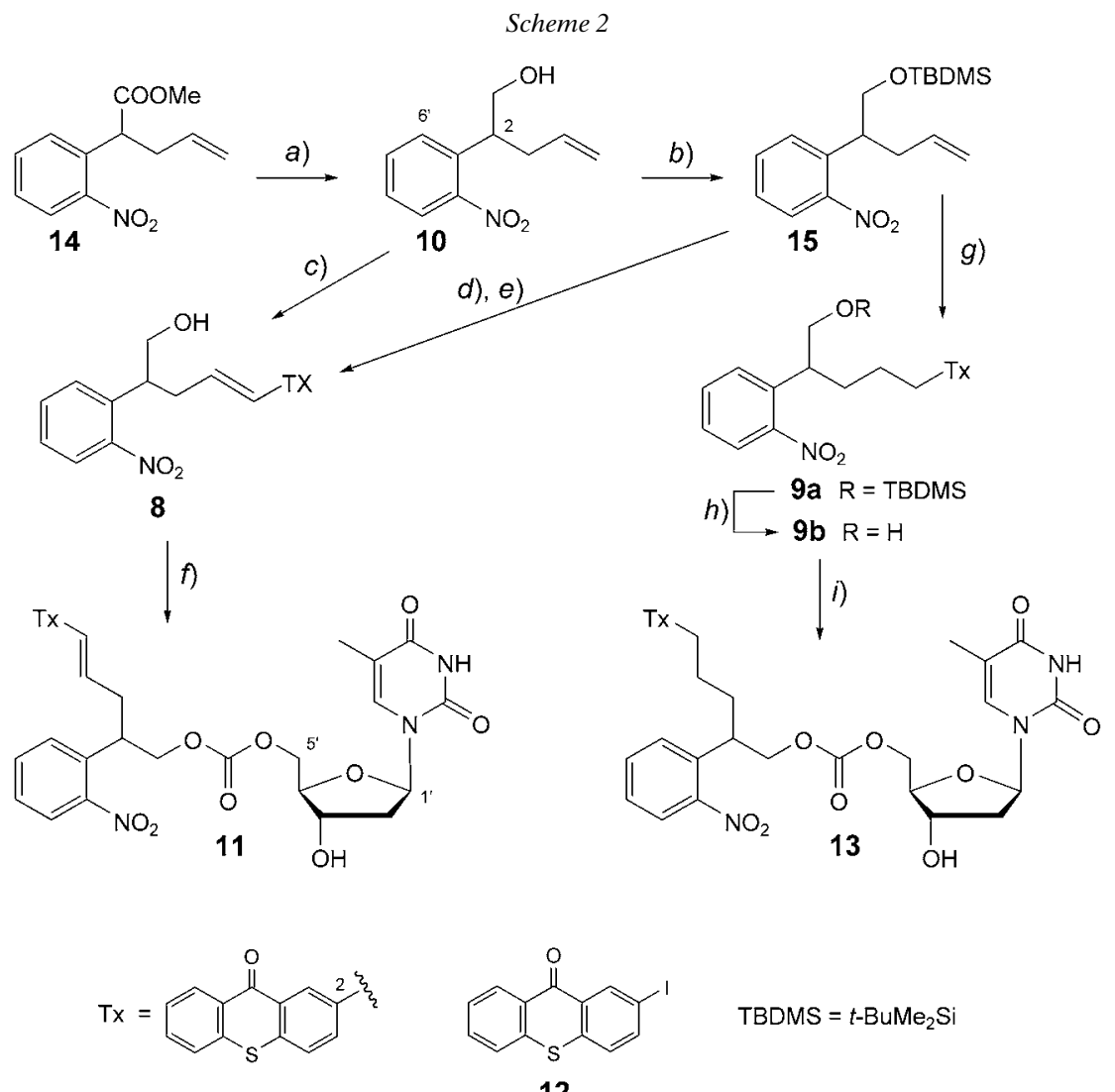

a) $\mathrm{NaBH}_{4}$, THF, MeOH, r.t., $3 \mathrm{~h} ; 81 \%$. b) $t$ - $\mathrm{BuMe}_{2} \mathrm{SiCl}$, imidazole, $\mathrm{CH}_{2} \mathrm{Cl}_{2}, 0^{\circ} \rightarrow$ r.t., 12 h; $98 \%$. c) $\mathbf{1 2}$ $\left[\mathrm{Pd}(\mathrm{OAc})_{2}\right], \mathrm{Bu}_{3} \mathrm{P}, \mathrm{K}_{2} \mathrm{CO}_{3}, \mathrm{DMF}, 100^{\circ}, 3 \mathrm{~h} ; 24 \%$. d) 12, [Pd(OAc) $\left.)_{2}\right], \mathrm{Bu}_{3} \mathrm{P}, \mathrm{K}_{2} \mathrm{CO}_{3}, \mathrm{DMF}, 100^{\circ}, 3$ h. $\left.e\right) \mathrm{Bu}_{4} \mathrm{NF}$, $\mathrm{THF}, 0^{\circ} \rightarrow$ r.t., $18 \mathrm{~h} ; 43 \%$ (2 steps).f) $1.20 \%$ soln. of phosgene in toluene, THF, $0^{\circ} \rightarrow$ r.t., 12 h; 2 . thymidine, pyridine, $\mathrm{CH}_{2} \mathrm{Cl}_{2}, 0^{\circ} \rightarrow$ r.t., $12 \mathrm{~h} ; 34 \%$. g) 1. 9-BBN, THF, r.t., $3 \mathrm{~h} ; 2 . \mathbf{1 2}$, [Pd(dppf) $\left.\mathrm{Cl}_{2}\right]$, $3 \mathrm{M}$ aq. $\mathrm{K}_{3} \mathrm{PO}_{4}, \mathrm{DMF}$, $100^{\circ}, 2$ h. $\left.h\right) \mathrm{Bu}_{4} \mathrm{NF}, \mathrm{THF}, 0^{\circ} \rightarrow$ r.t., 17 h, $47 \%$ (2 steps).i) 1 . Diphosgene, $\mathrm{Et}_{3} \mathrm{~N}, \mathrm{THF}, 0^{\circ} \rightarrow$ r.t., 4 h, 2. thymidine, pyridine, $\mathrm{CH}_{2} \mathrm{Cl}_{2}, 0^{\circ}, 48 \mathrm{~h} ; 58 \%$.

For the synthesis of the protecting group $\mathbf{1 6 b}$ with a saturated $\mathrm{C}_{2}$ linkage, we followed the same synthetic strategy based on the hydroboration-Suzuki coupling tandem reaction, as used for the synthesis of $\mathbf{9 b}$. To follow this synthetic approach, the silyl-protected form $\mathbf{1 7 b}$ of the alcohol 17a was required as key intermediate. The synthesis of $\mathbf{1 6 b}$ started from 1-allyl-2-nitro-benzene (18), which was prepared according to Sapountzis and Knochel [32]. Compound $\mathbf{1 8}$ was treated with paraformaldehyde in the presence of $t$-BuOK [30] to give the alcohol 17a in $86 \%$ yield. Protection of the $\mathrm{OH}$ group with $t$ - $\mathrm{BuMe}{ }_{2} \mathrm{SiCl}$ [26][27] afforded the silyl ether 17b quantitatively. The position of the olefinic $\mathrm{C}=\mathrm{C}$ bond in compounds $\mathbf{1 7}$ was verified by ${ }^{1} \mathrm{H}-\mathrm{NMR}$ analysis, and was in agreement with literature data [33].

Hydroboration of $\mathbf{1 7 b}$ with 2 equiv. of 9-BBN proceeded smoothly [28][29]. The organoborane intermediate, when subjected to Suzuki coupling with 12, afforded the 


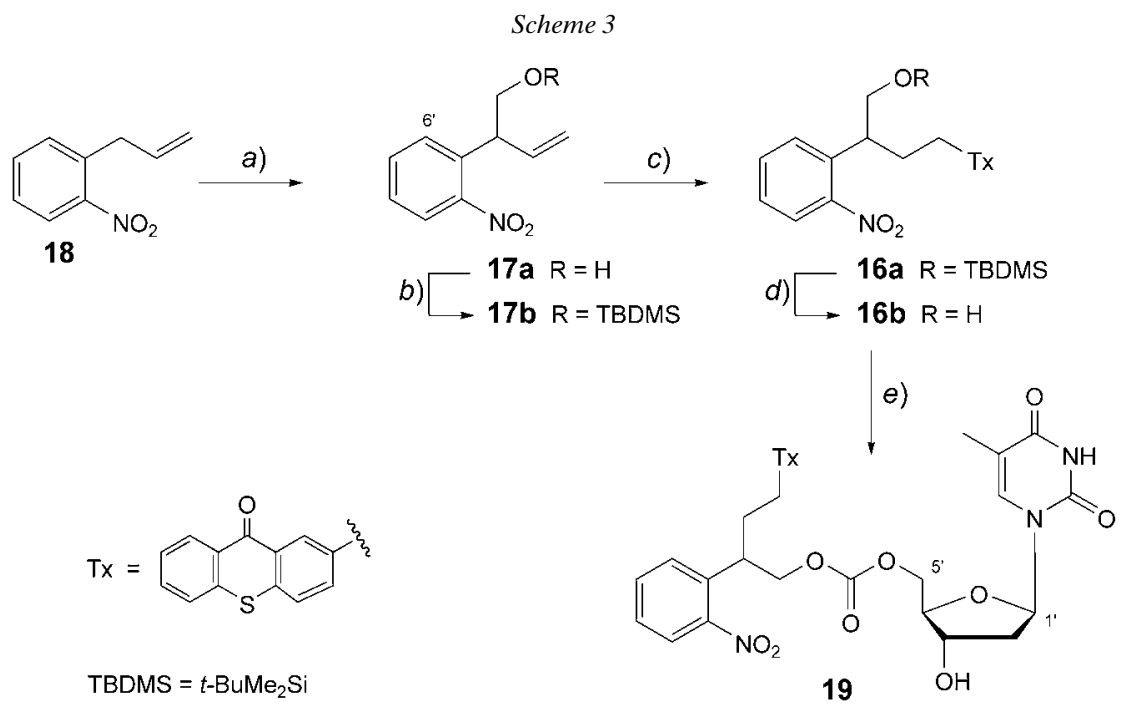

a) Paraformaldehyde, $t$-BuOK, DMSO, r.t., $2 \mathrm{~h} ; 86 \%$. b) $t$ - $\mathrm{BuMe}_{2} \mathrm{SiCl}$, imidazole, $\mathrm{CH}_{2} \mathrm{Cl}_{2}, 0^{\circ} \rightarrow$ r.t., $18 \mathrm{~h} ; 100 \%$. c) 1. 9-BBN, THF, r.t., 2 h, 2. 12, [Pd(dppf) $\left.\mathrm{Cl}_{2}\right], 3 \mathrm{M}$ aq. $\mathrm{K}_{3} \mathrm{PO}_{4}, \mathrm{DMF}, 100^{\circ}, 2.5$ h.d $) \mathrm{Bu}_{4} \mathrm{NF}, \mathrm{THF}, 0^{\circ} \rightarrow$ r.t., 18 h, $51 \% . e)$ 1. Diphosgene, $\mathrm{Et}_{3} \mathrm{~N}, \mathrm{THF}, 0^{\circ}, 2 \mathrm{~h} ; 2$. thymidine, pyridine, $\mathrm{CH}_{2} \mathrm{Cl}_{2}, 0^{\circ}, 20 \mathrm{~h}, 69 \%$.

desired silyl-protected alcohol 16a. The cleavage of the protecting group with $\mathrm{Bu}_{4} \mathrm{NF}$ in THF led to the alcohol 16b in two steps, in an overall yield of $51 \%$. The caged thymidine 19 was finally derived from $\mathbf{1 6 b}$ in $69 \%$ yield by the method described above for compound 13.

2. Linkage of the Thioxanthone Moiety to the Aromatic Ring of nppoc. Two synthetic pathways were developed for new protecting groups with a Tx residue linked to the aromatic ring of $\mathbf{1}$. In the first one, the protecting group was connected to the Tx moiety through an ester linkage (Scheme 4 ). In the second, Tx was directly attached to the aromatic ring of 1 (Scheme 5).

The synthesis of the 5'-O-caged thymidine 20, with the ester linkage at the aromatic ring of the nppoc moiety, is outlined in Scheme 4. The nitrobenzoic acid 21a was conveniently prepared from the known benzoic acid 22a [34], which was converted to the $t$-Bu ester 22b by DCC ( $=N, N$-dicyclohexylcarbodiimide $)$-mediated esterification [35]. Treatment of 22b with paraformaldehyde and $t$-BuOK afforded the alcohol $\mathbf{2 3}$, which was converted to the 2-(methoxyethoxy)methyl (MEM) ether 21a in $85 \%$ yield by treatment with $\mathrm{MEMCl}$ in the presence of Hünig base under standard conditions [36-38]. The $t$-Bu protecting group of 21a was smoothly cleaved under basic conditions (NaH, DMF) [39], without formation of any side products, to yield the desired benzoic acid derivative $\mathbf{2 1 b}$ in $94 \%$ yield. Attempts to remove the $t$-Bu group by the widely used acidolysis with anhydrous $\mathrm{CF}_{3} \mathrm{COOH}$ (TFA) were unsuccessful because of partial or complete cleavage of the MEM ether, contrary to literature data [40]. Reaction between 2-hydroxythioxanthene-9H-one (24) [41] and 21b in the presence of 1-(3-dimethylaminopropyl)-3-ethylcarbodiimide (EDCI) and $N, N$-dimethylpyridin-4-amine (DMAP) [42-44] resulted in the formation of aromatic ester 25a 


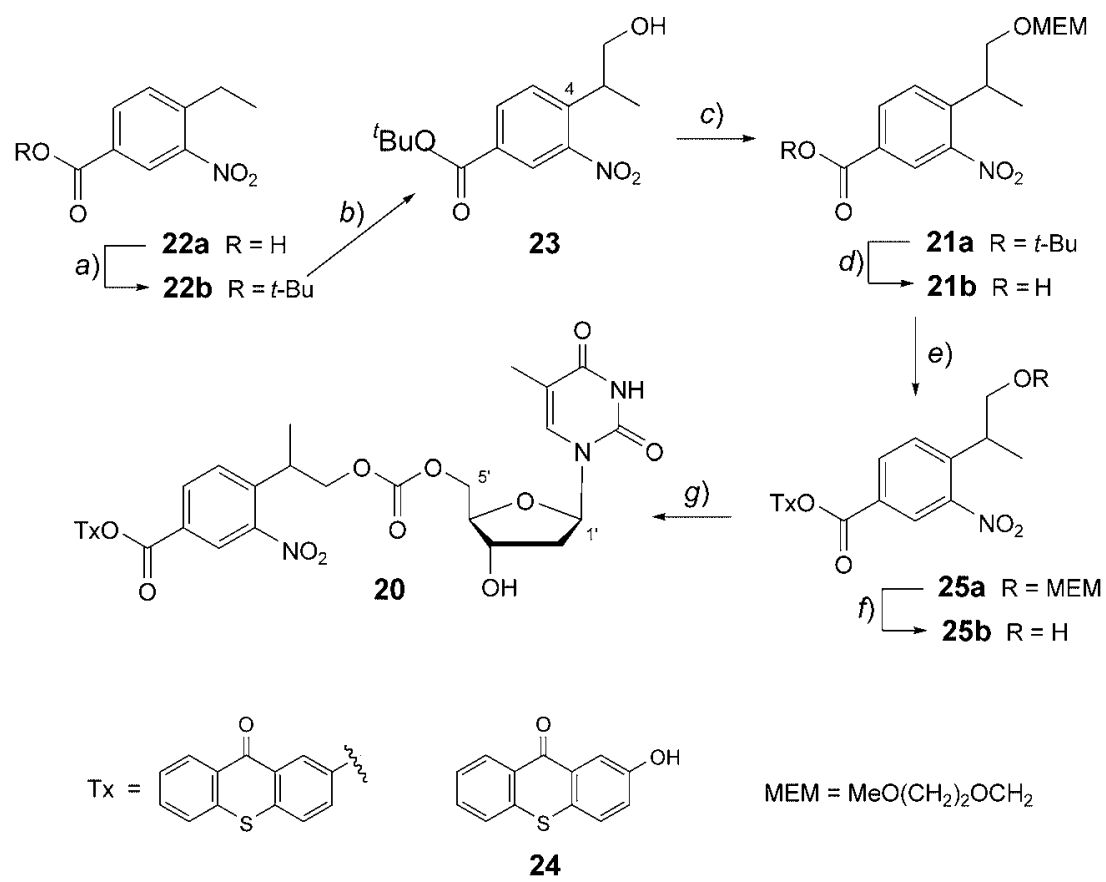

a) $t$-BuOH, DCC, DMAP, $\mathrm{CH}_{2} \mathrm{Cl}_{2}$, r.t., $3 \mathrm{~h} ; 96 \%$. b) Paraformaldehyde, $t$-BuOK, DMSO, r.t., $1 \mathrm{~h} ; 100 \%$. $c$ ) MEMCl, Et(i-Pr) ${ }_{2} \mathrm{~N}, \mathrm{CH}_{2} \mathrm{Cl}_{2}$, r.t., 21 h; $85 \%$.d) $\mathrm{NaH}$, DMF, r.t., 1 h; $94 \%$. e) 24, EDCI, DMAP, $\mathrm{CH}_{2} \mathrm{Cl}_{2}$, r.t., $24 \mathrm{~h} ; 64 \%$. f) $3 \mathrm{M}$ aq. $\mathrm{HCl}$, THF, $\left.75^{\circ}, 5 \mathrm{~h} ; 66 \% . g\right) 1$. Diphosgene, THF, $0^{\circ} \rightarrow$ r.t., $4 \mathrm{~h} ; 2$. thymidine, pyridine, $\mathrm{CH}_{2} \mathrm{Cl}_{2}, 0^{\circ}, 18 \mathrm{~h} ; 58 \%$.

in $64 \%$ yield. The MEM protecting group was removed with $3 \mathrm{M}$ aqueous $\mathrm{HCl}$ in $\mathrm{THF}$ under reflux [45][46] to yield the alcohol 25b. Reaction with diphosgene, and reaction of the resulting chloroformate with thymidine, analogous to the method described above, proceeded in $58 \%$ yield.

The protective group 26, bearing the Tx moiety directly linked to the aromatic ring of the nppoc chromophore, was synthesized by Suzuki-Miyaura reaction [47] between 6 and 2-(5-bromo-2-nitrophenyl)propan-1-ol (27), which was prepared according to [30]. Cross-coupling to $\mathbf{2 6}$ could be achieved by a one-pot procedure avoiding separation and purification of the intermediate 28. First, the dioxaborolan 28 was prepared in situ from 6 in dioxane using $\left[\mathrm{Pd}(\mathrm{dppf})_{2}\right](3 \mathrm{~mol}-\%)$ and $\mathrm{AcOK}$ (3 equiv. ) in the presence of the bis( pinacolate)diborane 29. Subsequent reaction of $\mathbf{2 8}$ with $\mathbf{2 7}$ in the presence of a new portion of $\left[\mathrm{Pd}(\mathrm{dppf})_{2}\right](3 \mathrm{~mol} \%)$ and $3 \mathrm{M}$ aqueous $\mathrm{K}_{3} \mathrm{PO}_{4}(3$ equiv.) led to the target compound $\mathbf{2 6}$ in $77 \%$ yield. By comparison, the traditional method involving isolation of $\mathbf{2 8}$ and reacting it, in a separate step, with $\mathbf{2 7}$ in THF led to $\mathbf{2 6}$ in only $\mathbf{3 9 \%}$ overall yield. The caged thymidine $\mathbf{3 0}$ was finally derived from $\mathbf{2 6}$ in $59 \%$ yield by treatment with phosgene, followed by reaction of the resulting chloroformate with thymidine, as described above. 
<smiles>CC(C)(C)OB(OB(OC(C)(C)C)OC(C)(C)C)OC(C)(C)C</smiles><smiles>[Y]c1ccc([N+](=O)[O-])c(C(C)CO)c1</smiles>
26 $\stackrel{\text { c) }}{\longrightarrow}$<smiles>[Y8]c1ccc([N+](=O)[O-])c(C(C)COC(=O)OC[C@H]2O[C@@H]3C[C@@H]2O[C@@H]3n2cc(C)c(=O)[nH]c2=O)c1</smiles><smiles>[Y]=[V]</smiles><smiles>CCCc1cc(Br)ccc1[N+](=O)[O-]</smiles>

a) AcOK, [Pd(dppf $\left.)_{2}\right], 1,4$-dioxane, $70^{\circ}, 16$ h. b) 27, [Pd(dppf $\left.)_{2}\right], 3 \mathrm{M}$ aq. $\mathrm{K}_{3} \mathrm{PO}_{4}, 70^{\circ}, 20 \mathrm{~h}, 77 \%$ (2 steps). c) 1. $20 \%$ soln. of phosgene in toluene, THF, r.t., $14 \mathrm{~h} ; 2$. thymidine, pyridine, $-40^{\circ} \rightarrow 0^{\circ}$ for $4 \mathrm{~h}$, then r.t. for $48 \mathrm{~h}$; $59 \%$.

Conclusions. - We have developed synthetic methods for several new photolabile protecting groups wherein a thioxanthone moiety is covalently linked at different positions to the photolabile nppoc moiety 1. In general, the methods are based on Pdcatalyzed cross-coupling reactions. To the best of our knowledge, these are the first such reactions with halogenated thioxanthones.

\section{Experimental Part}

All reactions with moisture-sensitive reagents were performed in dry, $\mathrm{N}_{2}$-flushed glassware. THF was dried over Na/benzophenone. DMF was stored over 4-Å molecular sieves under $\mathrm{N}_{2}$. Silica gel 60 (203-400 mesh; Merck) was used for flash chromatography (FC) and column chromatography (CC). Thin-layer chromatography (TLC) was performed on precoated silica gel $60 F_{254}$ plates (Merck), detection by UV light at $254 \mathrm{~nm}$. Melting points (m.p.) were determined with a Büchi B-545 apparatus in open glass capillaries; uncorrected. Elemental analyses were carried out by the Microanalytical Laboratory of the Department of Chemistry at the University of Konstanz.

Methyl 2-(2-Nitrophenyl)pent-4-ynoate (4). $t$-BuOK $(1.85 \mathrm{~g}, 16.5 \mathrm{mmol})$ was added to a stirred soln. of 3 [48] (3.21 g, $16.4 \mathrm{mmol})$ and propargyl bromide $(1.3 \mathrm{ml}, 17.2 \mathrm{mmol})$ in THF $(20 \mathrm{ml})$ at $-80^{\circ}$. The cooling bath was removed, and stirring was continued for $12 \mathrm{~h}$. After quenching with $\mathrm{H}_{2} \mathrm{O}(30 \mathrm{ml})$, the mixture was extracted with $\mathrm{Et}_{2} \mathrm{O}(3 \times 30 \mathrm{ml})$, the combined org. phase was washed with $\mathrm{H}_{2} \mathrm{O}(30 \mathrm{ml})$, dried $\left(\mathrm{MgSO}_{4}\right)$, and evaporated. The residue was purified by FC (AcOEt/hexane $0: 100 \rightarrow 25: 75)$ to give $4(1.84 \mathrm{~g}, 48 \%)$. Orange oil. ${ }^{1} \mathrm{H}-\mathrm{NMR}$ $\left(400 \mathrm{MHz}, \mathrm{CDCl}_{3}\right): 7.98\left(d d, J=8.2,1.4, \mathrm{H}-\mathrm{C}\left(3^{\prime}\right)\right) ; 7.61\left(t d, J=7.6,1.2, \mathrm{H}-\mathrm{C}\left(5^{\prime}\right)\right) ; 7.53(d d, J=7.8,1.5$, $\left.\mathrm{H}-\mathrm{C}\left(6^{\prime}\right)\right) ; 7.46\left(t d, J=7.7,1.5, \mathrm{H}-\mathrm{C}\left(4^{\prime}\right)\right) ; 4.45(d d, J=8.3,6.4, \mathrm{H}-\mathrm{C}(2)) ; 3.69(s, \mathrm{Me}) ; 3.03(d d d, J=17.0,6.2$, $2.7,1 \mathrm{H}$ of $\left.\mathrm{CH}_{2}\right) ; 2.85\left(d d d, J=17.0,8.3,2.7,1 \mathrm{H}\right.$ of $\left.\mathrm{CH}_{2}\right) ; 1.95(t, J=2.5,1 \mathrm{H}, \equiv \mathrm{CH})$.

2-(2-Nitrophenyl)pent-4-yn-1-ol (5). $\mathrm{NaBH}_{4}(525 \mathrm{mg}, 13.9 \mathrm{mmol})$ was added to a stirred soln. of $4(1.84 \mathrm{~g}$, $78.9 \mathrm{mmol})$ in $t$ - $\mathrm{BuOH}(25 \mathrm{ml})$. The suspension was heated to $80^{\circ}, \mathrm{MeOH}(3.4 \mathrm{ml}, 83.9 \mathrm{mmol})$ was added 
dropwise over a period of $4 \mathrm{~h}$, and heating was continued for $1 \mathrm{~h}$. After cooling to r.t. and quenching with $\mathrm{H}_{2} \mathrm{O}$ $(30 \mathrm{ml})$, the product was extracted with $\mathrm{Et}_{2} \mathrm{O}(3 \times 30 \mathrm{ml})$, the combined org. phase was washed with sat. aq. $\mathrm{NH}_{4} \mathrm{Cl}$ soln. $(30 \mathrm{ml})$, dried $\left(\mathrm{MgSO}_{4}\right)$, and evaporated to give pure $5(1.26 \mathrm{~g}, 78 \%)$. Viscous, red oil. ${ }^{1} \mathrm{H}-\mathrm{NMR}$ $\left(400 \mathrm{MHz}, \mathrm{CDCl}_{3}\right): 7.80\left(d, J=7.6, \mathrm{H}-\mathrm{C}\left(3^{\prime}\right)\right) ; 7.61-7.55$ ( $m, 2$ arom. H); $7.42-7.37$ ( $m$, arom. H); $4.03-3.95$ ( $m$, $\left.\mathrm{OCH}_{2}\right) ; 3.63$ (quint., $\left.\mathrm{H}-\mathrm{C}(2)\right) ; 2.72\left(d d d, J=17.1,6.8,2.7, \mathrm{H}_{\mathrm{a}}-\mathrm{C}(3)\right) ; 2.67\left(d d d, J=16.8,7.0,2.7, \mathrm{H}_{\mathrm{b}}-\mathrm{C}(3)\right)$; $1.98(t, J=2.5, \equiv \mathrm{CH})$.

2-[5-Hydroxy-4-(2-nitrophenyl)pent-1-yn-1-yl]-9H-thioxanthen-9-one (2). To a stirred soln. of 6 (735 mg, $2.52 \mathrm{mmol})$ [49] in anh. THF (20 ml), CuI (32 mg, $0.17 \mathrm{mmol}),\left[\mathrm{Pd}\left(\mathrm{PPh}_{3}\right)_{4}\right](48 \mathrm{mg}, 0.042 \mathrm{mmol})$, and $\mathrm{Et}_{3} \mathrm{~N}$ $(5 \mathrm{ml}, 35.9 \mathrm{mmol})$ were added in this order. Then, a soln. of $\mathbf{5}(511 \mathrm{mg}, 2.49 \mathrm{mmol})$ in anh. THF $(5 \mathrm{ml})$ was added dropwise over a period of $2 \mathrm{~h}$ at r.t. The mixture was stirred overnight, and the solvent was evaporated. The residue was taken up in $\mathrm{Et}_{2} \mathrm{O}(20 \mathrm{ml})$ and sat. aq. $\mathrm{NH}_{4} \mathrm{Cl}$ soln. $(20 \mathrm{ml})$, the org. phase was separated, and the aq. phase was re-extracted with $\mathrm{Et}_{2} \mathrm{O}(2 \times 10 \mathrm{ml})$. The combined org. phases were dried $\left(\mathrm{MgSO}_{4}\right)$, and the solvent was evaporated. Purification by FC (AcOEt/hexane $0: 100 \rightarrow 35: 65)$ afforded $2(318 \mathrm{mg}, 31 \%)$. Colorless foam. ${ }^{1} \mathrm{H}-\mathrm{NMR}\left(400 \mathrm{MHz}, \mathrm{CDCl}_{3}\right): 8.59(d d, J=8.2,1.4, \mathrm{H}-\mathrm{C}(8)(\mathrm{Tx})) ; 8.53(d, J=1.7, \mathrm{H}-\mathrm{C}(1)$ $(\mathrm{Tx})) ; 7.83\left(d, J=8.8\right.$, arom. H); $7.65-7.39\left(m, 8\right.$ arom. H); $4.10\left(d d, J=16.8,6.1,1 \mathrm{H}\right.$ of $\left.\mathrm{OCH}_{2}\right) ; 4.06(d d, J=$ 16.6, 6.4, $1 \mathrm{H}$ of $\left.\mathrm{OCH}_{2}\right) ; 3.75$ (quint.,$J=6.8$, benzylic $\left.\mathrm{CH}\right) ; 3.00\left(d d, J=17.0,6.6,1\right.$ of $\left.\mathrm{CH}_{2}\right) ; 2.91(d d, J=17.0$, $6.9,1 \mathrm{H}$ of $\left.\mathrm{CH}_{2}\right)$.

5'-O-(\{[2-(2-Nitrophenyl)-5-(9-oxo-9H-thioxanthen-2-yl)pent-4-yn-1-yl]oxy\}carbonyl)thymidine (7). To a stirred soln. of $2(318 \mathrm{mg}, 0.765 \mathrm{mmol})$ in anh. THF $(10 \mathrm{ml})$, a $20 \%$ soln. of phosgene in toluene $(3 \mathrm{ml})$ was added, and the reaction mixture was stirred at r.t. for $14 \mathrm{~h}$. The solvents were evaporated, and the chloroformate residue was dissolved in anh. $\mathrm{CH}_{2} \mathrm{Cl}_{2}(10 \mathrm{ml})$. In another flask, thymidine $(200 \mathrm{mg}, 0.83 \mathrm{mmol}$, dried for $5 \mathrm{~h}$ in vасио ) was dissolved in anh. pyridine $(10 \mathrm{ml})$. The thymidine soln. was cooled to $-40^{\circ}$, and the chloroformate soln. was added dropwise over $4 \mathrm{~h}$ with stirring. During the addition, the temp. was maintained between $-30^{\circ}$ to $0^{\circ}$. The mixture was allowed to warm to r.t., and stirring was continued for $2 \mathrm{~d}$. Removal of the solvents, coevaporation of the residue with toluene $(3 \times 5 \mathrm{ml})$, and $\mathrm{FC}\left(\mathrm{MeOH} / \mathrm{CH}_{2} \mathrm{Cl} 0: 100 \rightarrow 5: 95\right)$ gave $7(81 \mathrm{mg}, 15 \%)$. Colorless solid. M.p. 79-81 ${ }^{\circ}{ }^{1} \mathrm{H}-\mathrm{NMR}\left(400 \mathrm{MHz},\left(\mathrm{D}_{6}\right) \mathrm{DMSO}\right): 11.27(s, \mathrm{NH}) ; 8.45(d d, J=8.1,1.2, \mathrm{H}-\mathrm{C}(8)$ $(\mathrm{Tx})) ; 8.29(d, J=1.7, \mathrm{H}-\mathrm{C}(1)(\mathrm{Tx})) ; 7.91(d, J=8.1$, arom. H); $7.88-7.72(m, 5$ arom. H); $7.64-7.52$ ( $m, 3$ arom.

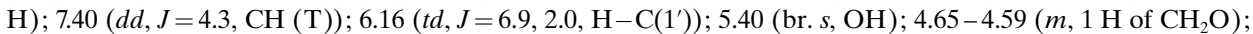
$4.54-4.48\left(m, 1 \mathrm{H}\right.$ of $\left.\mathrm{CH}_{2} \mathrm{O}\right) ; 4.31-4.17\left(m, \mathrm{CH}_{2}\left(5^{\prime}\right), \mathrm{H}-\mathrm{C}\left(3^{\prime}\right)\right) ; 3.92-3.88\left(m, \mathrm{H}-\mathrm{C}\left(4^{\prime}\right)\right) ; 3.82$ (quint., $J=6.8$, benzylic $\mathrm{CH}) ; 3.02\left(d d, J=17.3,6.4,1 \mathrm{H}\right.$ of $\left.\mathrm{CH}_{2}-\mathrm{C} \equiv\right) ; 2.93\left(d d, J=17.2,7.9,1 \mathrm{H}\right.$ of $\left.\mathrm{CH}_{2}-\mathrm{C} \equiv\right) ; 2.15-2.05(m$, $\left.\mathrm{CH}_{2}\left(2^{\prime}\right)\right) ; 1.72\left(d, J=3.2\right.$, Me). MALDI-MS (matrix: DHB): $683.2\left(M^{+}, \mathrm{C}_{35} \mathrm{H}_{29} \mathrm{~N}_{3} \mathrm{O}_{10} \mathrm{~S}^{+}\right)$.

2-(2-Nitrophenyl)pent-4-ene-1-ol $\mathbf{( 1 0})$. MeOH $(20 \mathrm{ml})$ was added slowly within $3 \mathrm{~h}$ to a stirred suspension of 14 [21] $(8.80 \mathrm{~g}, 37.4 \mathrm{mmol})$ and $\mathrm{NaBH}_{4}(8.80 \mathrm{~g}, 232 \mathrm{mmol})$ in anh. THF $(100 \mathrm{ml})$ under $\mathrm{N}_{2}$ atmosphere at r.t. Stirring was continued overnight. $\mathrm{H}_{2} \mathrm{O}(10 \mathrm{ml})$ was added, and, after $10 \mathrm{~min}$ of vigorous stirring, the solvents were evaporated. The residue was partitioned between $\mathrm{CH}_{2} \mathrm{Cl}_{2}(100 \mathrm{ml})$ and $\mathrm{H}_{2} \mathrm{O}(100 \mathrm{ml})$, the org. layer was separated, the aq. layer was extracted with $\mathrm{CH}_{2} \mathrm{Cl}_{2}(3 \times 30 \mathrm{ml})$, and the combined org. layers were washed with $\mathrm{H}_{2} \mathrm{O}(100 \mathrm{ml})$, dried $\left(\mathrm{MgSO}_{4}\right)$, and concentrated. A yellow oil ( $\left.7.2 \mathrm{~g}, 34.9 \mathrm{mmol}, 93 \%\right)$ was obtained, which was used for the next step without further purification. ${ }^{1} \mathrm{H}-\mathrm{NMR}\left(250 \mathrm{MHz}, \mathrm{CDCl}_{3}\right): 7.74\left(d d, J=8.1,1.2, \mathrm{H}-\mathrm{C}\left(3^{\prime}\right)\right)$; $7.61-7.47\left(m, \mathrm{H}-\mathrm{C}\left(5^{\prime}\right), \mathrm{H}-\mathrm{C}\left(6^{\prime}\right)\right) ; 7.36\left(t d, J=7.0,1.6, \mathrm{H}-\mathrm{C}\left(4^{\prime}\right)\right) ; 5.69(d d t, J=17.1,10.1,7.1, \mathrm{H}-\mathrm{C}(4)) ; 5.05-$ $4.94\left(m, \mathrm{CH}_{2}(5)\right) ; 3.93-3.78\left(m, \mathrm{CH}_{2}(1)\right) ; 3.49$ (quint., $\left.J=6.7, \mathrm{H}-\mathrm{C}(2)\right) ; 2.62-2.36\left(m, \mathrm{CH}_{2}(3)\right)$; 1.67 (br. $s$, $\mathrm{OH})$.

5-\{[tert-Butyl(dimethyl)silyl]oxy\}-4-(2-nitrophenyl)pent-1-ene $\left.(\mathbf{1 5})^{1}\right)$. To an ice-cold soln. of $\mathbf{1 0}(7.2 \mathrm{~g}$, $35 \mathrm{mmol})$ in anh. $\mathrm{CH}_{2} \mathrm{Cl}_{2}(150 \mathrm{ml}), 1 H$-imidazole $(3.0 \mathrm{~g}, 44 \mathrm{mmol})$ and $t$-BuMe $2 \mathrm{SiCl}(5.9 \mathrm{~g}, 39 \mathrm{mmol})$ were added with stirring. The cooling bath was removed, and the mixture was stirred at r.t. for $12 \mathrm{~h}$. The reaction was quenched with $\mathrm{MeOH}(20 \mathrm{ml})$, and after $10 \mathrm{~min}$ of stirring, sat. aq. $\mathrm{NaHCO}_{3}$ soln. $(100 \mathrm{ml})$ was added. The org. layer was separated, and the aq. phase was re-extracted with $\mathrm{CH}_{2} \mathrm{Cl}_{2}(3 \times 30 \mathrm{ml})$. The combined org. phases were washed with sat. aq. $\mathrm{NaHCO}_{3}$ soln. $(15 \mathrm{ml})$, dried $\left(\mathrm{MgSO}_{4}\right)$, and evaporated. The crude product was purified by FC (hexane/AcOEt $8: 1)$ to give $\mathbf{1 5}(11.2 \mathrm{~g}, 90 \%)$. Light yellow oil. ${ }^{1} \mathrm{H}-\mathrm{NMR}\left(250 \mathrm{MHz}, \mathrm{CDCl}_{3}\right): 7.72$ $\left(d d, J=8.5,1.8, \mathrm{H}-\mathrm{C}\left(3^{\prime}\right)\right) ; 7.49-7.52\left(m, \mathrm{H}-\mathrm{C}\left(5^{\prime}\right), \mathrm{H}-\mathrm{C}\left(6^{\prime}\right)\right) ; 7.26-7.35\left(m, \mathrm{H}-\mathrm{C}\left(4^{\prime}\right)\right) ; 5.70(d d t, J=17.1,10.1$, 7.1, $\mathrm{H}-\mathrm{C}(2)) ; 5.05-4.92\left(m, \mathrm{CH}_{2}(1)\right) ; 3.83-3.72\left(m, \mathrm{CH}_{2}(5)\right) ; 3.49-3.38(m, \mathrm{H}-\mathrm{C}(4)) ; 2.69-2.56$ ( $m$, $\left.\mathrm{H}_{\mathrm{a}}-\mathrm{C}(3)\right) ; 2.49-2.36\left(m, \mathrm{H}_{\mathrm{b}}-\mathrm{C}(3)\right) ; 0.82(s, t-\mathrm{Bu}) ;-0.06(s, \mathrm{Me}) ;-0.09(s, \mathrm{Me})$.

2-[5-Hydroxy-4-(2-nitrophenyl)pent-1-enyl]-9H-thioxanthen-9-one (8). Method A. To a stirred soln. of 10 (104 mg, $0.5 \mathrm{mmol})$ in anh., degassed DMF $(5 \mathrm{ml})$, kept under $\mathrm{N}_{2}$ atmosphere, $\mathrm{K}_{2} \mathrm{CO}_{3}(76 \mathrm{mg}, 0.55 \mathrm{mmol})$,

1) Systematic silane nomenclature was avoided for the sake of clarity. 
[Pd(OAc) $)_{2}$ (12 mg, $\left.0.05 \mathrm{mmol}\right), \mathrm{Bu}_{3} \mathrm{P}(25 \mu \mathrm{l}, 0.1 \mathrm{mmol})$, and $\mathbf{1 2}$ [19][20] (186 mg, $\left.0.55 \mathrm{mmol}\right)$ were rapidly added at r.t., and in the order mentioned. The flask was covered with Al foil, and the mixture was heated at $100^{\circ}$ for $3 \mathrm{~h}$. After cooling to r.t., brine $(10 \mathrm{ml})$ and $\mathrm{Et}_{2} \mathrm{O}(10 \mathrm{ml})$ were added under $\mathrm{N}_{2}$ atmosphere. The org. phases were separated, the aq. phase was re-extracted with $\mathrm{Et}_{2} \mathrm{O}(10 \mathrm{ml})$, the combined org. layer was dried $\left(\mathrm{MgSO}_{4}\right)$, and the solvent was evaporated. CC (AcOEt/hexane $10: 90 \rightarrow 60: 40)$ followed by crystallization from hexane/ $\mathrm{Et}_{2} \mathrm{O} 1: 1$ afforded the desired coupling product $\mathbf{8}(50 \mathrm{mg}, 24 \%)$.

Method B. To a stirred soln. of $\mathbf{1 5}(322 \mathrm{mg}, 1.0 \mathrm{mmol})$ in anh. degassed DMF (10 ml), kept under $\mathrm{N}_{2}, \mathrm{~K}_{2} \mathrm{CO}_{3}$ (152 mg, $1.1 \mathrm{mmol}),\left[\mathrm{Pd}(\mathrm{OAc})_{2}\right](23 \mathrm{mg}, 0.1 \mathrm{mmol}), \mathrm{Bu}_{3} \mathrm{P}(49.4 \mu \mathrm{l}, 0.2 \mathrm{mmol})$, and 12 (372 mg, $\left.1.1 \mathrm{mmol}\right)$ were added rapidly at r.t., and in the order mentioned. The flask was covered with Al foil, and the mixture was heated at $100^{\circ}$ for $3 \mathrm{~h}$. After cooling to r.t., brine $(10 \mathrm{ml})$ was added. The mixture was extracted with $\mathrm{Et}_{2} \mathrm{O}(3 \times 20 \mathrm{ml})$, the combined org. layer was washed with $\mathrm{H}_{2} \mathrm{O}(2 \times 20 \mathrm{ml})$, dried $\left(\mathrm{MgSO}_{4}\right)$, and evaporated. CC $($ AcOEt/hexane $10: 90 \rightarrow 25: 75)$ gave the corresponding silyl-protected coupling product $\left.{ }^{2}\right)$ as an impure mixture. This crude product $(532 \mathrm{mg})$ was dissolved in THF $(10 \mathrm{ml})$ and treated at $0^{\circ}$ with $\mathrm{Bu}_{4} \mathrm{NF}(1 \mathrm{M}$ soln. in $\mathrm{THF}, 1.4 \mathrm{ml}$, $1.4 \mathrm{mmol})$. The mixture was then stirred at r.t. for $16 \mathrm{~h}$, and extracted with $\mathrm{CH}_{2} \mathrm{Cl}_{2}(20 \mathrm{ml}$ and $10 \mathrm{ml})$. The combined org. phase was washed with sat. aq. $\mathrm{NH}_{4} \mathrm{Cl}$ soln. $(20 \mathrm{ml})$, dried $\left(\mathrm{MgSO}_{4}\right)$, and evaporated. The crude product was purified as described in Method $A$ to afford $8(178 \mathrm{mg})$ in $43 \%$ overall yield.

Data of 8. Yellow powder. M.p $132-133^{\circ} .{ }^{1} \mathrm{H}-\mathrm{NMR}\left(250 \mathrm{MHz},\left(\mathrm{D}_{6}\right) \mathrm{DMSO}\right): 8.45(d d, J=8.2,1.2, \mathrm{H}-\mathrm{C}(8)$ $(\mathrm{Tx})) ; 8.27(s, \mathrm{H}-\mathrm{C}(1)(\mathrm{Tx})) ; 7.85-7.40(m, 9$ arom. H); $6.52(d, J=15.9, \mathrm{Tx}-\mathrm{CH}=) ; 6.33(d t, J=15.9,7.0$, $\left.\mathrm{CH}_{2} \mathrm{CH}=\right) ; 4.89(t, J=5.19, \mathrm{OH}) ; 3.72-3.58\left(m, \mathrm{OCH}_{2}\right) ; 3.33(m$, benzylic $\mathrm{CH}$, partly masked by water signal); $2.82-2.72\left(m, 1 \mathrm{H}\right.$ of $\left.\mathrm{CH}_{2} \mathrm{CH}=\right) ; 2.63-2.54\left(m, 1 \mathrm{H}\right.$ of $\left.\mathrm{CH}_{2} \mathrm{CH}=\right)$. Anal. calc. for $\mathrm{C}_{24} \mathrm{H}_{19} \mathrm{NO}_{4} \mathrm{~S}(417.48): \mathrm{C} 69.05$, H 4.59, N 3.36; found: C 68.87, H 4.76, N 3.43 .

Data of Silyl-Protected Intermediate $\left.{ }^{2}\right):{ }^{1} \mathrm{H}-\mathrm{NMR}\left(250 \mathrm{MHz}, \mathrm{CDCl}_{3}\right): 8.61(d, J=8.0,1 \mathrm{H}, \mathrm{H}-\mathrm{C}(8)(\mathrm{Tx}))$; $8.43(d, J=1.2, \mathrm{H}-\mathrm{C}(1)(\mathrm{Tx})) ; 7.72(d d, J=7.3,1.2, \mathrm{H}-\mathrm{C}(3)) ; 7.43-7.67$ ( $m, 7$ arom. H) ; $7.29-7.40(m$, arom. $\mathrm{H}) ; 6.49(d, J=15.6, \mathrm{Tx}-\mathrm{CH}=) ; 6.26\left(d t, J=15.9,6.7, \mathrm{CH}_{2} \mathrm{CH}=\right) ; 3.90-3.76\left(m, \mathrm{OCH}_{2}\right) ; 3.61-3.51(m$, benzylic $\mathrm{CH}) ; 2.93-2.79\left(m, 1 \mathrm{H}\right.$ of $\left.\mathrm{CH}_{2} \mathrm{CH}=\right) ; 2.70-2.55\left(m, 1 \mathrm{H}\right.$ of $\left.\mathrm{CH}_{2} \mathrm{CH}=\right) ; 0.84(s, t-\mathrm{Bu}) ;-0.04(s, \mathrm{Me})$; $-0.06(s, \mathrm{Me})$.

5'-O-(\{[2-(2-Nitrophenyl)-5-(9-oxo-9H-thioxanthen-2-yl)pent-4-en-1-yl]oxy\}carbonyl)thymidine (11). To a stirred soln. of $\mathbf{8}(67 \mathrm{mg}, 0.16 \mathrm{mmol})$ in anh. THF $(2 \mathrm{ml})$, a $20 \%$ soln. of phosgene in toluene $(0.9 \mathrm{ml})$ was added dropwise via syringe under $\mathrm{N}_{2}$ atmosphere at $0^{\circ}$. The cooling bath was removed, and the mixture was stirred for $12 \mathrm{~h}$ at r.t. Monitoring by TLC indicated complete consumption of the starting material and the formation of the corresponding chloroformate $\left(R_{\mathrm{f}} 0.60\left(\mathrm{CH}_{2} \mathrm{Cl}_{2}\right)\right)$. The solvent was evaporated, the residue was co-evaporated with anh. $\mathrm{CH}_{2} \mathrm{Cl}_{2}(3 \times 2 \mathrm{ml})$, and the chloroformate intermediate was dissolved in anh. $\mathrm{CH}_{2} \mathrm{Cl}_{2}(1 \mathrm{ml})$. In a separate flask, thymidine $(39 \mathrm{mg}, 0.16 \mathrm{mmol})$ was first co-evaporated with anh. pyridine $(2 \times 1 \mathrm{ml})$, and then dissolved in anh. pyridine $(1 \mathrm{ml})$. To the stirred thymidine soln., the chloroformate soln. was added dropwise via syringe under $\mathrm{N}_{2}$ at $0^{\circ}$. The mixture was stirred at this temp. for $2 \mathrm{~h}$, then an additional $2 \mathrm{~h}$ at r.t., and was finally kept for $12 \mathrm{~h}$ at $10^{\circ}$. The solvent was evaporated, the oily residue was dissolved in $\mathrm{CH}_{2} \mathrm{Cl}_{2}(15 \mathrm{ml})$, and washed with $0.1 \mathrm{M}$ aq. $\mathrm{HCl}$ soln. $(3 \times 10 \mathrm{ml})$. The combined aq. layer was re-extracted with $\mathrm{CH}_{2} \mathrm{Cl}_{2}(2 \times 5 \mathrm{ml})$. The combined org. phase was dried $\left(\mathrm{MgSO}_{4}\right)$, and the solvent was evaporated. Purification by $\mathrm{CC}\left(\mathrm{MeOH} / \mathrm{CH}_{2} \mathrm{Cl}{ }_{2}\right.$ $0: 100 \rightarrow 4: 96)$ followed by crystallization from $\mathrm{Et}_{2} \mathrm{O}$ afforded 11 (41 mg, 34\%). Yellow powder. M.p. $152-154^{\circ}$. ${ }^{1} \mathrm{H}-\mathrm{NMR}\left(400 \mathrm{MHz},\left(\mathrm{D}_{6}\right) \mathrm{DMSO}\right): 11.24$ (br. $\left.s, \mathrm{NH}\right) ; 8.44(d, J=8.1, \mathrm{H}-\mathrm{C}(8)(\mathrm{Tx})) ; 8.27$ (br. $\left.s, \mathrm{H}-\mathrm{C}(1)(\mathrm{Tx})\right)$; $7.82-7.73(m, 5$ arom. H); $7.69(t, J=7.0$, arom. H) $7.57(t, J=8.1$, arom. H); $7.47(t, J=8.1$, arom. H); $7.37(d d$, $J=3.8,0.9, \mathrm{CH}(\mathrm{T})) ; 6.52(d, J=16.2, \mathrm{Tx}-\mathrm{CH}=) ; 6.30\left(d t, J=16.2,6.7, \mathrm{CH}_{2} \mathrm{CH}=\right) ; 6.19-6.12\left(m, \mathrm{H}-\mathrm{C}\left(1^{\prime}\right)\right)$; $5.38\left(d, J=4.4,3^{\prime}-\mathrm{OH}\right) ; 4.53-4.35\left(m, \mathrm{CHCH}_{2} \mathrm{O}\right) ; 4.26-4.15\left(m, \mathrm{H}-\mathrm{C}\left(3^{\prime}\right), \mathrm{CH}_{2}\left(5^{\prime}\right)\right) ; 3.91-3.84\left(m, \mathrm{H}-\mathrm{C}\left(4^{\prime}\right)\right)$; 3.65 (quint., $J=6.7$, benzylic $\mathrm{CH}) ; 2.80-2.60\left(m, \mathrm{CH}_{2} \mathrm{CH}=\right) ; 2.13-2.05\left(m, \mathrm{CH}_{2}\left(2^{\prime}\right)\right) ; 1.69(d, J=4.6, \mathrm{Me})$. Anal. calc. for $\mathrm{C}_{35} \mathrm{H}_{31} \mathrm{~N}_{3} \mathrm{O}_{10} \mathrm{~S} \cdot 0.5 \mathrm{H}_{2} \mathrm{O}$ (694.71): C 59.74, H 4.73, N 5.97; found: C 59.92, H 4.78, N 6.05.

2-[5-Hydroxy-4-(2-nitrophenyl)pentyl]-9H-thioxanthen-9-one (9b). 9-Borabicyclo[3.3.1]nonane (9-BBN; $0.5 \mathrm{M}$ in THF, $60 \mathrm{ml}, 30 \mathrm{mmol})$ was added dropwise to a stirred soln. of $\mathbf{1 5}(6.7 \mathrm{~g}, 20.8 \mathrm{mmol})$ in anh. THF (15 ml) over a period of $1 \mathrm{~h}$ under $\mathrm{N}_{2}$ atmosphere. The mixture was stirred for $4 \mathrm{~h}$. In a separate flask, a cat. amount of [Pd(dppf)Cl ${ }_{2}$ ( $\left.0.50 \mathrm{~g}, 0.68 \mathrm{mmol}, 3 \mathrm{~mol}-\%\right)$, aq. $\mathrm{K}_{3} \mathrm{PO}_{4}$ (3M soln., $8 \mathrm{ml}, 24 \mathrm{mmol}$ ), and degassed DMF (60 ml) were mixed in this order under $\mathrm{N}_{2}$ atmosphere. After $15 \mathrm{~min}$, compound 6 (6.3 g, $21.6 \mathrm{mmol}$ ) was added with vigorous stirring, followed by dropwise addition of the above borane via syringe. The flask was covered with $\mathrm{Al}$ foil, and the mixture was stirred at $80^{\circ}$ for $4 \mathrm{~h}$. After cooling to r.t., the mixture was taken up in $\mathrm{Et}_{2} \mathrm{O}(150 \mathrm{ml})$ and brine $(100 \mathrm{ml})$. The aq. layer was re-extracted with $\mathrm{Et}_{2} \mathrm{O}(3 \times 30 \mathrm{ml})$, and the combined org. phase was

2) 2-[5-\{[tert-Butyl(dimethyl)silyl]oxy\}-4-(2-nitrophenyl)pent-1-enyl]-9H-thioxanthen-9-one. 
washed with sat. aq. $\mathrm{NaHCO}_{3}$ soln. $(50 \mathrm{ml})$, dried $\left(\mathrm{MgSO}_{4}\right)$, and evaporated. The crude product was subjected to FC (AcOEt/hexane $3.5: 96.5 \rightarrow 8: 92$ ) to afford the silyl-protected product $9 \mathbf{a}^{3}$ ) (contaminated with borate), which was used without further purification. Crude 9a $(7.72 \mathrm{~g}, 14.5 \mathrm{mmol})$ was dissolved in THF (120 ml) and treated with $\mathrm{Bu}_{4} \mathrm{NF} \cdot 3 \mathrm{H}_{2} \mathrm{O}(6.3 \mathrm{~g}, 20 \mathrm{mmol})$ under stirring at $0^{\circ}$. The cooling bath was removed, and the mixture was stirred for $15 \mathrm{~h}$ at r.t., diluted with $\mathrm{Et}_{2} \mathrm{O}(100 \mathrm{ml})$, and washed with sat. aq. $\mathrm{NH}_{4} \mathrm{Cl}$ soln. $(50 \mathrm{ml})$. The combined aq. layer was re-extracted with $\mathrm{Et}_{2} \mathrm{O}(20 \mathrm{ml})$. The combined org. phase was dried $\left(\mathrm{MgSO}_{4}\right)$ and evaporated. Purification by CC (AcOEt/hexane $5: 95 \rightarrow 50: 50$ ) and crystallization from hexane afforded $\mathbf{9 b}$ (4.07 g, 47\% based on $\mathbf{1 5})$.

Data of 9a. ${ }^{1} \mathrm{H}-\mathrm{NMR}\left(250 \mathrm{MHz}, \mathrm{CDCl}_{3}\right): 8.62(d d, J=7.9,1.2, \mathrm{H}-\mathrm{C}(8)(\mathrm{Tx})) ; 8.38(d, J=1.8, \mathrm{H}-\mathrm{C}(1)$ $(\mathrm{Tx})) ; 7.68\left(d d, J=7.9,1.2, \mathrm{H}-\mathrm{C}\left(3^{\prime}\right)\right) ; 7.62-7.39(m, 7$ arom. $\mathrm{H}) ; 7.31\left(t d, J=7.9,1.5, \mathrm{H}-\mathrm{C}\left(4^{\prime}\right)\right) ; 3.70(d, J=5.8$, $\left.\mathrm{CH}_{2} \mathrm{O}\right) ; 3.42-3.31(m, \mathrm{CH}) ; 2.77-2.69\left(m, \mathrm{Tx}-\mathrm{CH}_{2}\right) ; 1.34-1.75\left(m,\left(\mathrm{CH}_{2}\right) \mathrm{C}_{2}\right) ; 0.77(s, t-\mathrm{Bu}) ;-0.10(s, \mathrm{Me})$; $-0.11(s, \mathrm{Me})$.

Data of $\left.\mathbf{9 b}^{3}\right)$. Light yellow solid. M.p. $115-117^{\circ} .{ }^{1} \mathrm{H}-\mathrm{NMR}\left(250 \mathrm{MHz},\left(\mathrm{D}_{6}\right) \mathrm{DMSO}\right): 8.46(d d, J=8.2,1.0$, $\mathrm{H}-\mathrm{C}(8)(\mathrm{Tx})) ; 8.22(d, J=1.5, \mathrm{H}-\mathrm{C}(1)(\mathrm{Tx})) ; 7.86-7.66\left(m, 8\right.$ arom. H) $7.42\left(t d, J=7.9,1.5, \mathrm{H}-\mathrm{C}\left(4^{\prime}\right)\right) ; 4.77(t$, $J=5.2, \mathrm{OH}) ; 3.60-3.45\left(m, \mathrm{CH}_{2} \mathrm{O}\right) ; 3.17-3.07(m, \mathrm{CH}) ; 2.70\left(t, J=7.0, \mathrm{Tx}-\mathrm{CH}_{2}\right) ; 1.40-1.70\left(m,\left(\mathrm{CH}_{2}\right)_{2}\right)$. Anal. calc. for $\mathrm{C}_{24} \mathrm{H}_{21} \mathrm{NO}_{4} \mathrm{~S}$ (419.49): C 68.72, H 5.05, N 3.36; found: C 68.64, H 5.11, N 3.40 .

5'-O-(\{[2-(2-Nitrophenyl)-5-(9-oxo-9H-thioxanthen-2-yl)pentyl]oxy\} carbonyl)thymidine (13). To an icecold soln. of trichloromethyl chloroformate $(171 \mu \mathrm{l}, 1.41 \mathrm{mmol})$ in anh. THF $(5 \mathrm{ml})$ was added dropwise a soln. of $9 \mathbf{b}(443 \mathrm{mg}, 1.06 \mathrm{mmol})$ and $\mathrm{Et}_{3} \mathrm{~N}(148 \mu \mathrm{l}, 1.06 \mathrm{mmol})$ in anh. THF $(5 \mathrm{ml})$. The mixture was stirred for $2 \mathrm{~h}$ at $0^{\circ}$, and then for $2 \mathrm{~h}$ at r.t., until TLC monitoring indicated complete consumption of $\mathbf{9 b}$ and formation of the chloroformate $\left(R_{\mathrm{f}} 0.51\left(\mathrm{CH}_{2} \mathrm{Cl}_{2}\right)\right)$. The solid was filtered off and washed with anh. THF. The solvent was evaporated, and the residue was dissolved in anh. $\mathrm{CH}_{2} \mathrm{Cl}_{2}(5 \mathrm{ml})$. In a separate flask, thymidine $(257 \mathrm{mg}$, $1.06 \mathrm{mmol})$ was first co-evaporated with anh. pyridine $(4 \times 5 \mathrm{ml})$, and then dissolved in anh. pyridine $(5 \mathrm{ml})$. To the stirred thymidine soln., the above chloroformate soln. was added via syringe at $0^{\circ}$, and the mixture was kept at this temp. for $2 \mathrm{~d}$. The solvents were evaporated, the residue was co-evaporated with EtOH $(4 \times 5 \mathrm{ml})$, then with $\mathrm{CH}_{2} \mathrm{Cl}_{2}(3 \times 5 \mathrm{ml})$. The crude product was purified by $\mathrm{FC}\left(\mathrm{MeOH} / \mathrm{CH}_{2} \mathrm{Cl}_{2} 0.5: 95.5 \rightarrow 5: 95\right)$ and crystallized from $\mathrm{EtO}_{2}$ to give $13(422 \mathrm{mg}, 58 \%)$. Light yellow powder. M.p. $100-102^{\circ} .{ }^{1} \mathrm{H}-\mathrm{NMR}(250 \mathrm{MHz}$, ( $\left.\mathrm{D}_{6}\right) \mathrm{DMSO}$ ): 11.29 (br. $\left.s, \mathrm{NH}\right) ; 8.45(d d, J=8.2,1.2, \mathrm{H}-\mathrm{C}(8)(\mathrm{Tx})) ; 8.22(d, J=1.8, \mathrm{H}-\mathrm{C}(1)(\mathrm{Tx})) ; 7.85-7.47$ $(m, 9$ arom. $\mathrm{H}) ; 7.37(d d, J=4.8,0.9, \mathrm{CH}(\mathrm{T})) ; 6.15\left(t, J=7.0, \mathrm{H}-\mathrm{C}\left(1^{\prime}\right)\right) ; 5.41\left(d, J=4.3,3^{\prime}-\mathrm{OH}\right) ; 4.38-4.12(m$, $\left.\mathrm{CH}_{2} \mathrm{O}, \mathrm{CH}_{2}\left(5^{\prime}\right), \mathrm{H}-\mathrm{C}\left(3^{\prime}\right)\right) ; 3.87\left(m, \mathrm{H}-\mathrm{C}\left(4^{\prime}\right)\right) ; 3.43-3.37(m, \mathrm{CH}) ; 2.73-2.65\left(m, \mathrm{Tx}-\mathrm{CH}_{2}\right) ; 2.12-2.04(m$, $\left.\mathrm{CH}_{2}\left(2^{\prime}\right)\right), 1.85-1.69\left(m, \mathrm{CH}_{2}\right) ; 1.69(d, J=2.7, \mathrm{Me}) ; 1.61-1.37\left(m, \mathrm{CH}_{2}\right)$. Anal. calc. for $\mathrm{C}_{35} \mathrm{H}_{33} \mathrm{~N}_{3} \mathrm{O}_{10} \mathrm{~S} \cdot 0.5 \mathrm{H} \mathrm{H}_{2} \mathrm{O}$ (696.72): C 60.33, H 4.91, N 6.03; found: C 60.40, H 5.07, N 5.93.

2-(2-Nitrophenyl)but-3-en-1-ol (17a). To a stirred soln. of 18 [32] (462 mg, $2.83 \mathrm{mmol})$ in anh. DMSO $(2 \mathrm{ml})$, paraformaldehyde (128 $\mathrm{mg} 4.25 \mathrm{mmol})$ was added, and the suspension was treated with $t$-BuOK $(13 \mathrm{mg}$, $0.11 \mathrm{mmol})$. The mixture was stirred at r.t. for $2 \mathrm{~h}$, and then poured into brine $(40 \mathrm{ml})$. The product was extracted with AcOEt $(3 \times 20 \mathrm{ml})$, the combined org. phase was washed with brine $(20 \mathrm{ml}), \mathrm{H}_{2} \mathrm{O}(2 \times 30 \mathrm{ml})$, dried $\left(\mathrm{MgSO}_{4}\right)$, and evaporated. Purification by FC (AcOEt/hexane $\left.20: 80 \rightarrow 40: 60\right)$ afforded 17a $(472 \mathrm{mg}$, $86 \%)$. Light yellowish oil. ${ }^{1} \mathrm{H}-\mathrm{NMR}\left(250 \mathrm{MHz},\left(\mathrm{D}_{6}\right) \mathrm{DMSO}\right): 7.82\left(d d, J=8.2,1.2, \mathrm{H}-\mathrm{C}\left(3^{\prime}\right)\right) ; 7.66(t d, J=7.0$, $\left.1.2, \mathrm{H}-\mathrm{C}\left(5^{\prime}\right)\right) ; 7.59\left(d d, J=7.8,1.5, \mathrm{H}-\mathrm{C}\left(6^{\prime}\right)\right) ; 7.46\left(t d, J=8.2,1.8, \mathrm{H}-\mathrm{C}\left(4^{\prime}\right)\right) ; 6.02(d d d, J=17.4,10.4,7.0$, $\mathrm{H}-\mathrm{C}(3)) ; 5.12\left(d t, J=10.4,1.2, \mathrm{H}_{\mathrm{a}}-\mathrm{C}(4)\right) ; 5.02\left(d t, J=17.4,1.2, \mathrm{H}_{\mathrm{b}}-\mathrm{C}(4)\right) ; 4.87($ br., $\mathrm{OH}) ; 3.94-3.83(m, \mathrm{CH})$; 3.76-3.60 $\left(m, \mathrm{OCH}_{2}\right)$. Anal. calc. for $\mathrm{C}_{10} \mathrm{H}_{11} \mathrm{NO}_{3}(193.20)$ : C 62.17, H 5.74, N 7.25; found: C 61.72, H 5.90, N 7.26.

4-\{[(tert-Butyl)(dimethyl)silyl]oxy\}-3-(2-nitrophenyl)but-1-ene (17b). Prepared from 17a (410 mg, $2.12 \mathrm{mmol}$ ), imidazole $(361 \mathrm{mg}, 5.30 \mathrm{mmol})$ and $t$ - $\left.\mathrm{BuMe} \mathrm{SiCl}_{2} \mathrm{Sig} \mathrm{mg}, 4.24 \mathrm{mmol}\right)$, as described for $\mathbf{1 5}$, followed by FC (hexane/AcOEt $12: 1$ ): $651 \mathrm{mg}$ (quant.). Light yellowish oil. ${ }^{1} \mathrm{H}-\mathrm{NMR}\left(250 \mathrm{MHz}, \mathrm{CDCl}_{3}\right): 7.75$ $\left(d d, J=8.6,1.2, \mathrm{H}-\mathrm{C}\left(3^{\prime}\right)\right) ; 7.58-7.45\left(m, \mathrm{H}-\mathrm{C}\left(5^{\prime}\right), \mathrm{H}-\mathrm{C}\left(6^{\prime}\right)\right) ; 7.34\left(t d, J=8.9,2.1, \mathrm{H}-\mathrm{C}\left(4^{\prime}\right)\right) ; 6.05(d d d, J=$ $17.2,10.7,6.7, \mathrm{CH}=) ; 5.19\left(d t, J=11.0,1.2,1 \mathrm{H}\right.$ of $\left.\mathrm{CH}_{2}=\right) ; 5.14\left(d t, J=17.4,1.2,1 \mathrm{H}\right.$ of $\left.\mathrm{CH}_{2}=\right) ; 4.16(d d, J=6.7$, $6.7, \mathrm{CH}) ; 3.91\left(d d, J=9.8,5.8,1 \mathrm{H}\right.$ of $\left.\mathrm{CH}_{2} \mathrm{OSi}\right) ; 3.85\left(d d, J=9.8,6.7,1 \mathrm{H}\right.$ of $\left.\mathrm{CH}_{2} \mathrm{OSi}\right) ; 0.73(s, t-\mathrm{Bu}) ;-0.06(s$, $\mathrm{Me}) ;-0.07(s, \mathrm{Me})$. The product was used without further purification.

2-[4-Hydroxy-3-(2-nitrophenyl)butyl]-9H-thioxanthen-9-one (16b). Prepared from 17b (421 mg, $1.37 \mathrm{mmol}), 9-\mathrm{BBN}(0.5 \mathrm{M}$ soln. in THF, $5.5 \mathrm{ml}, 2.74 \mathrm{mmol}), \mathbf{1 2}(435 \mathrm{mg}, 1.29 \mathrm{mmol}),\left[\mathrm{Pd}(\mathrm{dppf}) \mathrm{Cl}_{2}\right](47 \mathrm{mg}$, $0.065 \mathrm{mmol})$, and aq. $3 \mathrm{M} \mathrm{K}_{3} \mathrm{PO}_{4}$ soln. $(0.86 \mathrm{ml}, 2.58 \mathrm{mmol})$, as described for $\mathbf{9 b}$. The silyl-protected intermediate 16a was purified by FC (AcOEt/hexane $3.5: 96.5 \rightarrow 30: 70)$, and the $t-\mathrm{BuMe}_{2} \mathrm{Si}$ group was cleaved with $\mathrm{Bu}_{4} \mathrm{NF}$

3) 2-[5-\{[tert-Butyl(dimethyl)silyl]oxy\}-4-(2-nitrophenyl)pentyl]-9H-thioxanthen-9-one. 
(1M soln. in THF, $1.8 \mathrm{ml}, 1.8 \mathrm{mmol})$ in THF $(10 \mathrm{ml})$, as described above. Purification by CC (AcOEt/hexane $15: 85 \rightarrow 50: 50)$ and crystallization from hexane afforded $\mathbf{1 6 b}(266 \mathrm{mg}, 51 \%$ from $\mathbf{1 2})$.

Data of 16a. ${ }^{1} \mathrm{H}-\mathrm{NMR}\left(250 \mathrm{MHz}, \mathrm{CDCl}_{3}\right): 8.62(d, J=8.0, \mathrm{H}-\mathrm{C}(8)(\mathrm{Tx})) ; 8.36(d, J=1.5, \mathrm{H}-\mathrm{C}(1)(\mathrm{Tx}))$; $7.72\left(d, J=7.9, \mathrm{H}-\mathrm{C}\left(3^{\prime}\right)\right) ; 7.66-7.31(m, 8$ arom. $\mathrm{H}) ; 3.78\left(d, J=5.5, \mathrm{CH}_{2} \mathrm{O}\right) ; 3.45-3.36(m, \mathrm{CH}) ; 2.81-2.59(m$, $\left.\mathrm{CH}_{2}\right) ; 2.34-2.03\left(m, \mathrm{CH}_{2}\right) ; 0.81(s, t-\mathrm{Bu}) ;-0.07(s, \mathrm{Me}) ;-0.08(s, \mathrm{Me})$.

Data of 16b. Colorless solid. M.p. $100-112{ }^{\circ} .{ }^{1} \mathrm{H}-\mathrm{NMR}\left(250 \mathrm{MHz},\left(\mathrm{D}_{6}\right) \mathrm{DMSO}\right): 8.46(d d, J=8.2,1.5$, $\mathrm{H}-\mathrm{C}(8)(\mathrm{Tx})) ; 8.20(d, J=1.5, \mathrm{H}-\mathrm{C}(1)(\mathrm{Tx})) ; 7.88-7.40(m, 9$ arom. $\mathrm{H}) ; 4.84(t, J=5.19, \mathrm{OH}) ; 3.66-3.54(m$, $\left.\mathrm{CH}_{2} \mathrm{O}\right) ; 3.22-3.10(m$, benzylic $\mathrm{CH}) ; 2.76-2.54\left(m, \mathrm{CH}_{2}\right) ; 2.28-1.90\left(m, \mathrm{CH}_{2} \mathrm{CH}\right)$. Anal. calc. for $\mathrm{C}_{23} \mathrm{H}_{19} \mathrm{NO}_{4} \mathrm{~S}$ (405.47): C 68.13, H 4.72, N 3.45; found: C 68.16, H 4.67, N 3.51.

5'-O-(\{[2-(2-Nitrophenyl)-4-(9-oxo-9H-thioxanthen-2-yl)butyl]oxy\} carbonyl)thymidine (19). Prepared as described for $\mathbf{1 3}$, from $\mathbf{1 6 b}(100 \mathrm{mg}, 0.27 \mathrm{mmol})$, trichloromethyl chloroformate $(43.4 \mu \mathrm{l}, 0.36 \mathrm{mmol})$, and $\mathrm{Et}_{3} \mathrm{~N}$ $(38 \mu \mathrm{l}, 0.27 \mathrm{mmol})$ in anh. THF $(4 \mathrm{ml})$, followed by reaction of the resulting chloroformate with thymidine $(65 \mathrm{mg}, 0.27 \mathrm{mmol})$ in anh. pyridine $/ \mathrm{CH}_{2} \mathrm{Cl}_{2} 1: 1(3 \mathrm{ml})$. Purification by $\mathrm{FC}\left(\mathrm{MeOH} / \mathrm{CH}_{2} \mathrm{Cl}_{2} 0: 100 \rightarrow 4: 96\right)$ followed by crystallization from $\mathrm{Et}_{2} \mathrm{O}: 126 \mathrm{mg}(69 \%)$ of 16b. Colorless powder. M.p. $110-112^{\circ}$. ${ }^{1} \mathrm{H}-\mathrm{NMR}$ (250 MHz, (D $)$ DMSO): 11.30 (br. $s, \mathrm{NH}) ; 8.46(d, J=7.9, \mathrm{H}-\mathrm{C}(8)(\mathrm{Tx})) ; 8.18(d, J=1.8, \mathrm{H}-\mathrm{C}(1)(\mathrm{Tx})) ; 7.87-$ $7.45\left(m, 9\right.$ arom. H) $7.38(d, J=6.10, \mathrm{CH}(\mathrm{T})) ; 6.16\left(t, J=6.10, \mathrm{H}-\mathrm{C}\left(1^{\prime}\right)\right) ; 5.43\left(d, J=4.3,3^{\prime}-\mathrm{OH}\right) ; 4.54-4.11$ $\left(m, \mathrm{H}-\mathrm{C}\left(3^{\prime}\right), \mathrm{CH}_{2}\left(5^{\prime}\right), \mathrm{CH}_{2}\right) ; 3.92-3.84\left(m, \mathrm{H}-\mathrm{C}\left(4^{\prime}\right)\right) ; 3.56-3.40(m$, benzylic $\mathrm{CH}) ; 2.80-2.53\left(m, \mathrm{CH}_{2}\right)$; $2.25-1.99\left(m, \mathrm{CH}_{2}\left(2^{\prime}\right), \mathrm{CH}_{2}\right) ; 1.68(d, J=4.8, \mathrm{Me})$. Anal. calc. for $\mathrm{C}_{34} \mathrm{H}_{31} \mathrm{~N}_{3} \mathrm{O}_{10} \mathrm{~S}(673.69): \mathrm{C} 60.62, \mathrm{H} 4.64, \mathrm{~N}$ 6.24; found: C $60.23, \mathrm{H} 4.60, \mathrm{~N} 6.30$

tert-Butyl 4-Ethyl-3-nitrobenzoate (22b). A stirred soln. of 22a [34] (4.5 g, $23.1 \mathrm{mmol})$, DMAP (342 mg, $2.3 \mathrm{mmol})$, and $t$-BuOH $(2.6 \mathrm{~g}, 35.1 \mathrm{mmol})$ in anh. $\mathrm{CH}_{2} \mathrm{Cl}_{2}(70 \mathrm{ml})$ was treated with DCC $(5.23 \mathrm{~g}, 25.4 \mathrm{mmol})$ at $0^{\circ}$. After $5 \mathrm{~min}$ of stirring at $0^{\circ}$, the cooling bath was removed, and the mixture was stirred at r.t. for $3 \mathrm{~h}$. The precipitate was suction-filtered, washed with $\mathrm{CH}_{2} \mathrm{Cl}_{2}$, and evaporated. To the oily residue containing a precipitate, hexane $(90 \mathrm{ml})$ was added. This mixture was passed through a short plug of $\mathrm{SiO}_{2}(7 \mathrm{~g})$ to remove insoluble dicyclohexylurea, and the pad was washed with hexane/AcOEt 50:1 (50 ml). The org. soln. was washed with $1 \mathrm{M}$ aq. $\mathrm{HCl}$ soln. $(2 \times 50 \mathrm{ml}), 5 \%$ aq. $\mathrm{K}_{2} \mathrm{CO}_{3}$ soln. $(50 \mathrm{ml})$, and dried $\left(\mathrm{MgSO}_{4}\right)$. Removal of the solvent afforded pure 22b $(5.57 \mathrm{~g}, 96 \%)$. Light yellowish oil. ${ }^{1} \mathrm{H}-\mathrm{NMR}\left(250 \mathrm{MHz}, \mathrm{CDCl}_{3}\right): 8.43(d, J=1.8$, $\mathrm{H}-\mathrm{C}(2)) ; 8.11(d d, J=8.2,1.8, \mathrm{H}-\mathrm{C}(6)) ; 7.42(d, J=7.9, \mathrm{H}-\mathrm{C}(5)) ; 2.95\left(q, J=7.3, \mathrm{CH}_{2}\right) ; 1.60(s, t-\mathrm{Bu}) ; 1.29(t$, $J=7.3, \mathrm{Me})$.

tert-Butyl 4-(2-Hydroxy-1-methylethyl)-3-nitrobenzoate (23). Prepared as described for 17a, starting from 22b $(4.24 \mathrm{~g}, 16.87 \mathrm{mmol})$, paraformaldehyde $(763 \mathrm{mg}, 25.41 \mathrm{mmol})$, and $t$-BuOK $(70 \mathrm{mg}, 0.62 \mathrm{mmol})$. Purification by FC (AcOEt/hexane $10: 90 \rightarrow 35: 65)$ gave $23(4.75 \mathrm{~g}, 100 \%)$. Yellow oil. ${ }^{1} \mathrm{H}-\mathrm{NMR}(250 \mathrm{MHz}$, $\left.\left(\mathrm{D}_{6}\right) \mathrm{DMSO}\right): 8.19(d, J=1.8, \mathrm{H}-\mathrm{C}(2)) ; 8.09(d d, J=8.2,1.5, \mathrm{H}-\mathrm{C}(6)) ; 7.75(d, J=8.2, \mathrm{H}-\mathrm{C}(5)) ; 4.79(t, J=$ $5.2, \mathrm{OH}) ; 3.55-3.49\left(m, \mathrm{CH}_{2}\right) ; 3.27(q, J=6.7$, benzylic $\mathrm{CH}) ; 1.55(s, t-\mathrm{Bu}) ; 1.24(d, J=7.0, \mathrm{Me})$.

tert-Butyl 4-\{2-[(2-Methoxyethoxy)methoxy]-1-methylethyl\}-3-nitrobenzoate (21a). To a stirred soln. of 23 $(4.75 \mathrm{~g}, 16.88 \mathrm{mmol})$ in anh. $\mathrm{CH}_{2} \mathrm{Cl}_{2}(15 \mathrm{ml})$ was added $\mathrm{Et}(\mathrm{i}-\mathrm{Pr})_{2} \mathrm{~N}(5.6 \mathrm{ml}, 32.07 \mathrm{mmol})$, followed by a soln. of $\mathrm{MeO}\left(\mathrm{CH}_{2}\right)_{2} \mathrm{OCH}_{2} \mathrm{Cl}(\mathrm{MEMCl} ; 2.9 \mathrm{ml}, 25.32 \mathrm{mmol})$ in anh. $\mathrm{CH}_{2} \mathrm{Cl}_{2}(10 \mathrm{ml})$. After $4 \mathrm{~h}$ of stirring at r.t., a new portion of $\mathrm{MEMCl}(0.5 \mathrm{ml}, 3.0 \mathrm{mmol})$ was added, and stirring was continued for $17 \mathrm{~h}$. The mixture was diluted with $\mathrm{CH}_{2} \mathrm{Cl}_{2}(60 \mathrm{ml})$ and washed with $0.1 \mathrm{M}$ aq. $\mathrm{HCl}$ soln. $(2 \times 30 \mathrm{ml})$, sat. aq. $\mathrm{NaCO}_{3}$ soln. $(30 \mathrm{ml})$, and $\mathrm{H}_{2} \mathrm{O}$ $(30 \mathrm{ml})$. The org. layer was separated, dried $\left(\mathrm{MgSO}_{4}\right)$, and evaporated. The crude product was purified by $\mathrm{FC}$ $($ AcOEt/hexane $10: 90 \rightarrow 35: 65)$ to give 21a $(5.31 \mathrm{~g}, 85 \%)$. Yellow oil. ${ }^{1} \mathrm{H}-\mathrm{NMR}\left(250 \mathrm{MHz}, \mathrm{CDCl}_{3}\right): 8.29(d, J=$ $1.8, \mathrm{H}-\mathrm{C}(2)) ; 8.13(d d, J=8.2,1.8, \mathrm{H}-\mathrm{C}(6)) ; 7.56(d, J=8.2, \mathrm{H}-\mathrm{C}(5)) ; 4.66-4.58\left(m, \mathrm{OCH}_{2} \mathrm{O}\right) ; 3.71-3.46(m$, benzylic $\left.\mathrm{CH}, \mathrm{CHCH}_{2} \mathrm{O}, 2 \mathrm{OCH}_{2}\right) ; 3.37(s, \mathrm{MeO}) ; 1.60(s, t$-Bu $) ; 1.34(d, J=6.74, \mathrm{Me})$. Anal. calc. for $\mathrm{C}_{18} \mathrm{H}_{27} \mathrm{NO}_{7}$ (369.41): C 58.52, H 7.37, N 3.79; found: C 58.32, H 7.40, N 3.98 .

4-\{2-[(2-Methoxyethoxy)methoxy]-1-methylethyl\}-3-nitrobenzoic Acid (21b). To a stirred suspension of $\mathrm{NaH}(60 \%$ dispersion in mineral oil; $2.24 \mathrm{~g}, 56 \mathrm{mmol})$ in anh. DMF $(15 \mathrm{ml})$, a soln. of $21 \mathrm{a}(2.59 \mathrm{~g}, 7.00 \mathrm{mmol})$ in DMF $(10 \mathrm{ml})$ was added. The mixture was stirred for $1 \mathrm{~h}$, and then carefully poured into $\mathrm{H}_{2} \mathrm{O}(160 \mathrm{ml})$. The aq. soln. was acidified with $3 \mathrm{M} \mathrm{HCl}$ to $\mathrm{pH} 4-5$, and extracted with $\mathrm{Et}_{2} \mathrm{O}(2 \times 70 \mathrm{ml})$. The combined org. layer was washed with $\mathrm{H}_{2} \mathrm{O}(4 \times 70 \mathrm{ml})$, dried $\left(\mathrm{MgSO}_{4}\right)$, and evaporated. The crude product was purified by FC (AcOEt/ hexane $25: 75 \rightarrow 50: 50)$ to afford $21 b(2.05 \mathrm{~g}, 94 \%)$. Yellow oil. ${ }^{1} \mathrm{H}-\mathrm{NMR}\left(250 \mathrm{MHz}, \mathrm{CDCl}_{3}\right): 8.45(d, J=1.8$, $\mathrm{H}-\mathrm{C}(2)) ; 8.23(d d, J=8.2,1.8, \mathrm{H}-\mathrm{C}(6)) ; 7.64(d, J=8.2, \mathrm{H}-\mathrm{C}(5)) ; 4.68-4.60\left(m, \mathrm{OCH}_{2} \mathrm{O}\right) ; 3.74-3.50(m$, benzylic $\left.\mathrm{CH}, \mathrm{CHCH}_{2} \mathrm{O}, 2 \mathrm{OCH}_{2}\right) ; 3.38(s, \mathrm{MeO}) ; 1.37\left(d, J=6.7\right.$, Me). Anal. calc. for $\mathrm{C}_{14} \mathrm{H}_{19} \mathrm{NO}_{7}(313.30)$ : C 53.67, H 6.11, N 4.47; found: C 53.55, H 6.26, N 4.61.

9-Oxo-9H-thioxanthen-2-yl 4-\{2-[(2-Methoxyethoxy)methoxy]-1-methylethyl $\}-3-n i t r o b e n z o a t e ~(25 a)$. To a stirred soln. of $\mathbf{2 1 b}(300 \mathrm{mg}, 0.96 \mathrm{mmol})$ in anh. DMF $(9 \mathrm{ml})$, DMAP (98 mg, $0.79 \mathrm{mmol}), 24(240 \mathrm{mg}$, $1.05 \mathrm{mmol}$ ) [41] , and EDCI (368 mg, $1.92 \mathrm{mmol})$ were added in this order. The mixture was stirred for $24 \mathrm{~h}$ at r.t. 
DMF was removed by co-evaporation with toluene, the oily residue was dissolved in $\mathrm{CH}_{2} \mathrm{Cl}_{2}(20 \mathrm{ml})$, and washed with sat. aq. $\mathrm{NH}_{4} \mathrm{Cl}$ soln. $(2 \times 15 \mathrm{ml}), 5 \%$ aq. $\mathrm{K}_{2} \mathrm{CO}_{3}$ soln. $(15 \mathrm{ml})$, and brine $(2 \times 15 \mathrm{ml})$. The org. phase was separated, dried $\left(\mathrm{MgSO}_{4}\right)$, and evaporated. Purification by FC (AcOEt/hexane $\left.10: 90 \rightarrow 50: 50\right)$ afforded 25a (321 mg, 64\%). Yellow oil. ${ }^{1} \mathrm{H}-\mathrm{NMR}\left(250 \mathrm{MHz}, \mathrm{CDCl}_{3}\right): 8.63(d d, J=8.2,1.5, \mathrm{H}-\mathrm{C}(8)(\mathrm{Tx})) ; 8.58(d, J=$ $1.8, \mathrm{H}-\mathrm{C}(2)) ; 8.45(d, J=2.4, \mathrm{H}-\mathrm{C}(1)(\mathrm{Tx})) ; 8.37(d d, J=8.2,1.8, \mathrm{H}-\mathrm{C}(6)) ; 7.73-7.49$ ( $m, 6$ arom. H) ; 4.69$4.63\left(m, \mathrm{OCH}_{2} \mathrm{O}\right) ; 3.77-3.49\left(m\right.$, benzylic $\left.\mathrm{CH}, \mathrm{CHCH}_{2} \mathrm{O}, 2 \mathrm{OCH}_{2}\right) ; 3.39(s, \mathrm{MeO}) ; 1.40(d, J=6.7$, Me $)$. Anal. calc. for $\mathrm{C}_{27} \mathrm{H}_{25} \mathrm{NO}_{8} \mathrm{~S}$ (523.56): C 61.94, H 4.81, N 2.68; found: C 61.92, H 4.78, N, 2.70.

9-Oxo-9H-thioxanthen-2-yl 4-(2-Hydroxy-1-methylethyl)-3-nitrobenzoate (25b). To a stirred soln. of 25a $(389 \mathrm{mg}, 0.74 \mathrm{mmol})$ in THF $(10 \mathrm{ml})$ was slowly added a $3 \mathrm{M}$ aq. $\mathrm{HCl}$ soln. $(10 \mathrm{ml})$ at $0^{\circ}$. The mixture was gently refluxed for $5 \mathrm{~h}$, cooled to r.t., and poured into chilled sat. aq. $\mathrm{NaHCO}_{3}$ soln. $(50 \mathrm{ml})$. After gas evolution had ceased, the mixture was extracted with $\mathrm{CH}_{2} \mathrm{Cl}_{2}(3 \times 20 \mathrm{ml})$, the combined org. phase was washed with sat. aq. $\mathrm{NaHCO}_{3}$ soln. $(20 \mathrm{ml})$ and brine $(2 \times 20 \mathrm{ml})$, dried $\left(\mathrm{MgSO}_{4}\right)$, and evaporated. Purification by FC (AcOEt/ hexane $20: 80 \rightarrow 60: 40)$ and crystallization from $\mathrm{Et}_{2} \mathrm{O}$ yielded $\mathbf{2 5 b}(212 \mathrm{mg}, 66 \%)$. Yellow crystals. M.p. 189$190^{\circ} .{ }^{1} \mathrm{H}-\mathrm{NMR}\left(250 \mathrm{MHz},\left(\mathrm{D}_{6}\right) \mathrm{DMSO}\right): 8.50-8.45(m, 2$ arom. $\mathrm{H}) ; 8.40-8.34(m, 2$ arom. H) ; $8.02(d, J=8.6$, arom. $\mathrm{H}) ; 7.93-7.77(m, 4$ arom. $\mathrm{H}) ; 7.62(t d, J=8.2,1.2$, arom. $\mathrm{H}) ; 4.89(t, J=5.2, \mathrm{OH}) ; 3.63-3.55\left(m, \mathrm{CH}_{2} \mathrm{O}\right)$; $3.35-3.26$ ( $m$, benzylic $\mathrm{CH}$, partly masked by water signal); $1.29(d, J=7.0, \mathrm{Me})$. Anal. calc. for $\mathrm{C}_{23} \mathrm{H}_{17} \mathrm{NO}_{6} \mathrm{~S}$ (435.45): C 63.44, H 3.94, N 3.22; found: C 63.30, H 3.93, N 3.25.

5'-O-\{[2-(2-Nitro-4-\{[(9-oxo-9H-thioxanthen-2-yl)oxy]carbonyl\}phenyl)propoxy]carbonyl\}thymidine (20). Prepared as described for $\mathbf{1 3}$, but starting from $\mathbf{2 5 b}(130 \mathrm{mg}, 0.30 \mathrm{mmol})$, by phosgenation with trichloromethyl chloroformate $(43 \mu \mathrm{l}, 0.40 \mathrm{mmol})$ in the presence of $\mathrm{Et}_{3} \mathrm{~N}(42 \mu \mathrm{l}, 0.30 \mathrm{mmol})$ in anh. THF $(4 \mathrm{ml})$, and subsequent reaction of the chloroformate with thymidine $(73 \mathrm{mg}, 0.30 \mathrm{mmol})$ in anh. pyridine $/ \mathrm{CH}_{2} \mathrm{Cl}_{2} 1: 1$ (4 ml). Purification by $\mathrm{FC}\left(\mathrm{MeOH} / \mathrm{CH}_{2} \mathrm{Cl}_{2} 0: 100 \rightarrow 5: 95\right)$ followed by crystallization from $\mathrm{Et}_{2} \mathrm{O}$ afforded $20(123 \mathrm{mg}$, $58 \%$ ). Light yellow solid. M.p. $162-164^{\circ} .{ }^{1} \mathrm{H}-\mathrm{NMR}\left(250 \mathrm{MHz},\left(\mathrm{D}_{6}\right) \mathrm{DMSO}\right): 11.33(\mathrm{~s}, \mathrm{NH}) ; 8.58-8.37(\mathrm{~m}, 3$ arom. $\mathrm{H}) ; 8.06-7.77(m, 5$ arom. $\mathrm{H}) ; 7.62(t d, J=8.2,1.2$, arom. H); $7.42-7.40(m, \mathrm{CH}(\mathrm{T})) ; 6.17(t, J=7.3$, $\left.\mathrm{H}-\mathrm{C}\left(1^{\prime}\right)\right) ; 5.45\left(d, J=4.3,3^{\prime}-\mathrm{OH}\right) ; 4.55-4.15\left(m, \mathrm{CH}_{2} \mathrm{O}, \mathrm{H}-\mathrm{C}\left(3^{\prime}\right), \mathrm{CH}_{2}\left(5^{\prime}\right)\right) ; 3.91-3.85\left(m, \mathrm{H}-\mathrm{C}\left(4^{\prime}\right)\right) ; 3.66-$ $3.57(m$, benzylic $\mathrm{CH}) ; 2.14-2.06\left(m, \mathrm{CH}_{2}\left(2^{\prime}\right)\right) ; 1.73(s, \mathrm{Me}(\mathrm{T})) ; 1.33(d, J=7.0, \mathrm{Me})$. Anal. calc. for $\mathrm{C}_{34} \mathrm{H}_{29} \mathrm{~N}_{3} \mathrm{O}_{12} \mathrm{~S} \cdot 0.5 \mathrm{H}_{2} \mathrm{O}$ (712.67): C 57.30, H 4.24, N 5.90; found: C 57.43, H 4.24, N 6.16.

2-[3-(2-Hydroxy-1-methylethyl)-4-nitrophenyl]-9H-thioxanthene-9-one (26). A mixture of $6(1.0 \mathrm{~g}$, $3.44 \mathrm{mmol}$ ), commercially available bis(pinacolate)diborane $29(1.05 \mathrm{~g}, 4.13 \mathrm{mmol})$, and AcOK (1.35 g, $13.76 \mathrm{mmol}$ ) in 1,4-dioxane $(50 \mathrm{ml})$ was degassed by gentle bubbling $\mathrm{N}_{2}$ through the stirred mixture for $30 \mathrm{~min}$. Then, $\left[\mathrm{Pd}(\mathrm{dppf}) \mathrm{Cl}_{2}\right.$ ] $(3 \mathrm{~mol}-\%, 76 \mathrm{mg}, 0.103 \mathrm{mmol})$ was added. The mixture was stirred at $65-70^{\circ}$ for $16 \mathrm{~h}$ under $\mathrm{N}_{2}$ atmosphere, and then cooled to r.t. A degassed soln. of 27 [30] (1.07 g, $\left.4.13 \mathrm{mmol}\right)$ in 1,4-dioxane $(6 \mathrm{ml})$ was added, followed by $\left[\mathrm{Pd}(\mathrm{dppf}) \mathrm{Cl}_{2}\right](3 \mathrm{~mol}-\%, 76 \mathrm{mg}, 0.103 \mathrm{mmol})$ and aq. $3 \mathrm{M} \mathrm{K}_{3} \mathrm{PO}_{4}$ soln. $(2.13 \mathrm{ml}$, $12.39 \mathrm{mmol}$ ), and in the order mentioned. The mixture was heated and stirred at $80^{\circ}$ for $7 \mathrm{~h}$ under $\mathrm{N}_{2}$ atmosphere. After cooling to r.t., the inorganic precipitate was filtered off, washed with $\mathrm{CH}_{2} \mathrm{Cl}_{2}$ and $\mathrm{H}_{2} \mathrm{O}$, and the filtrate was concentrated to $5-7 \mathrm{ml}$. EtOH $(15 \mathrm{ml})$ and $\mathrm{H}_{2} \mathrm{O}(15 \mathrm{ml})$ were added to the residue, and the suspension was sonicated for $5 \mathrm{~min}$. The precipitate was suction-filtered, washed with $50 \%$ aq. EtOH, suspended in $\mathrm{EtOH} / \mathrm{Et}_{2} \mathrm{O} 1: 1(25 \mathrm{ml})$, and sonicated for $5 \mathrm{~min}$. Filtration and washing with $\mathrm{EtOH} / \mathrm{Et}_{2} \mathrm{O} 1: 1$ afforded 26 $(1.04 \mathrm{~g}, 77 \%)$. Yellow powder. M.p. $174-176^{\circ} .{ }^{1} \mathrm{H}-\mathrm{NMR}\left(400 \mathrm{MHz},\left(\mathrm{D}_{6}\right) \mathrm{DMSO}\right): 8.74(d, J=1.9, \mathrm{H}-\mathrm{C}(1)$ $(\mathrm{Tx})) ; 8.50(d d, J=8.1,1.0, \mathrm{H}-\mathrm{C}(8)(\mathrm{Tx})) ; 8.19(d d, J=8.5,2.2$, arom. H); $8.03-7.80(m, 6$ arom. $\mathrm{H}) ; 7.62(t d$, $J=8.1,1.2, \mathrm{H}-\mathrm{C}(7)(\mathrm{Tx})) ; 4.81(t, J=5.4, \mathrm{OH}) ; 3.70-3.60\left(m, \mathrm{CH}_{2}\right) ; 3.37-3.29(m$, benzylic $\mathrm{CH}$, partly masked by water signal); $1.33(d, \mathrm{Me})$. Anal. calc. for $\mathrm{C}_{22} \mathrm{H}_{17} \mathrm{NO}_{4} \mathrm{~S}(391.44)$ : $\mathrm{C} 67.50, \mathrm{H} 4.38, \mathrm{~N} 3.58$; found: $\mathrm{C}$ $66.67, \mathrm{H} 5.03, \mathrm{~N} 3.65$.

5'-O-\{[2-(2-Nitro-5-\{[(9-oxo-9H-thioxanthen-2-yl)oxy]carbonyl $\}$ phenyl)propoxy]carbonyl $\}$ thymidine (30). Prepared as described for 11, starting from $26(480 \mathrm{mg}, 1.23 \mathrm{mmol})$, treated with a $20 \%$ soln. of phosgene in toluene $(4 \mathrm{ml})$, followed by reaction of the resulting chloroformate with thymidine $(388 \mathrm{mg}, 1.60 \mathrm{mmol})$ in anh. pyridine $/ \mathrm{CH}_{2} \mathrm{Cl}_{2} 1: 1(30 \mathrm{ml})$. The reaction was carried out at $-44^{\circ} \rightarrow$ r.t. for $20 \mathrm{~h}$. Purification by FC $\left(\mathrm{MeOH} / \mathrm{CH}_{2} \mathrm{Cl}_{2} 0: 100 \rightarrow 3: 97\right)$ yielded 30 (478 mg, 59\%). Yellow powder. M.p. $228-230^{\circ} .{ }^{1} \mathrm{H}-\mathrm{NMR}(400 \mathrm{MHz}$, $\left.\left(\mathrm{D}_{6}\right) \mathrm{DMSO}\right): 11.27(s, \mathrm{NH}) ; 8.78(d, J=2.0, \mathrm{H}-\mathrm{C}(1)(\mathrm{Tx})) ; 8.51(d, J=8.0, \mathrm{H}-\mathrm{C}(8)(\mathrm{Tx})) ; 8.20(d d, J=8.3$, 1.8 , arom. H); $8.08-7.80(m, 6$ arom. H); $7.63(t, J=7.5, \mathrm{H}-\mathrm{C}(7)(\mathrm{Tx})) ; 7.37(s, \mathrm{CH}(\mathrm{T})) ; 6.14(t, J=6.8$, $\left.\mathrm{H}-\mathrm{C}\left(1^{\prime}\right)\right) ; 5.38$ (br. $\left.s, \mathrm{OH}\right) ; 4.51-4.41\left(m, \mathrm{CH}_{2} \mathrm{O}\right) ; 4.26-4.15\left(m, \mathrm{H}-\mathrm{C}\left(3^{\prime}\right), \mathrm{CH}_{2}\left(5^{\prime}\right)\right) ; 3.91-3.86\left(m, \mathrm{H}-\mathrm{C}\left(4^{\prime}\right)\right)$; $3.64(q, J=6.7$, benzylic $\mathrm{CH}) ; 2.17-2.03\left(m, \mathrm{CH}_{2}\left(2^{\prime}\right)\right) ; 1.68(s, \mathrm{Me}(\mathrm{T})) ; 1.39(d, J=6.8, \mathrm{CH}-\mathrm{Me})$. Anal. calc. for $\mathrm{C}_{33} \mathrm{H}_{29} \mathrm{~N}_{3} \mathrm{O}_{10} \mathrm{~S}$ (659.66): C 60.08, H 4.43, N 6.37; found: C 58.00, H 4.41, N 6.38. 


\section{REFERENCES}

[1] R. J. Lipshutz, S. P. A. Fodor, T. R. Gingeras, D. J. Lockhart, Nature Genet. Suppl. 1999, 21, 20.

[2] M. C. Pirrung, Angew. Chem., Int. Ed. 2002, 41, 1276.

[3] D. Whitcombe, C. R. Newton, S. Little, Curr. Opin. Biotechnol. 1998, 9, 602.

[4] D. J. Duggan, M. Bittner, Y. Chen, P. Meltzer, J. M. Trent, Nature Genet. 1999, 21, 10.

[5] R. J. Lipshutz, S. P. A. Fodor, Curr. Opin. Struct. Biol. 1994, 4, 376.

[6] 'DNA Microarrays: A Practical Approach', Ed. M. Schena, Oxford Press, New York, 1999.

[7] 'Microarray Biochip Technology', Ed. M. Schena, Eaton, Natick, 2000.

[8] 'Methods in Molecular Biology, Vol. 170: DNA Arrays. Methods and Protocols', Ed. J. B. Rampa, Humana Press, Totowa, NJ, 2001.

[9] W. M. Freeman, D. J. Robertson, K. E. Vrana, Biotechniques 2000, 29, 1042

[10] J. Wang, Nucleic Acids Res. 2000, 28, 3011.

[11] D. H. Blohm, A. Guiseppe-Elie, Curr. Opin. Biotechnol. 2001, 12, 41.

[12] C. M. Niemeyer, D. Blohm, Angew. Chem., Int. Ed. 1999, 38, 2865.

[13] M. C. Pirrung, V. S. Rana, 'Photoremovable Protecting Groups in DNA Synthesis and Microarray Fabrication', in 'Dynamic Studies in Biology: Phototriggers, Photoswitches, and Caged Compounds', Eds. M. Goeldner, R. S. Givens, J. Wiley \& Sons, New York, 2005, p. 341.

[14] A. Hasan, K.-P. Stengele, H. Giegrich, P. Cornwell, K. R. Isham, R. A. Sachleben, W. Pfleiderer, R. S. Foote, Tetrahedron 1997, 53, 4247.

[15] S. Bühler, I. Lagoja, H. Giegrich, K.-P. Stengele, W. Pfleiderer, Helv. Chim. Acta 2004, 87, 620.

[16] D. Wöll, S. Walbert, K.-P. Stengele, T. Albert, T. Richmond, J. Norton, M. Singer, R. Green, W. Pfleiderer, U. E. Steiner, Helv. Chim. Acta 2004, 87, 28

[17] K. Soai, H. Oyamada, M. Takase, A. Ookawa, Bull. Chem. Soc. Jpn. 1984, 57, 1948.

[18] K. Sonogashira, in 'Metal-Catalyzed Cross-Coupling Reactions', Ed. F. Diederich, P. T. Stang, Wiley-VCH, Weinheim, 1997, 203.

[19] J.-K. Moon, J.-W. Park, W. S. Lee, Y.-J. Kang, H.-A. Chung, M.-S. Shin, Y.-J. Yoon, K. H. Park, J. Heterocycl. Chem. 1999, 36, 793.

[20] A. M. Schoevaars, W. Kruizinga, W. J. Zijlstra, N. Veldman, A. L. Spek, B. L. Feringa, J. Org. Chem. 1997, $62,4943$.

[21] R. A. Bunce, M. H. Derrick, L. B. Johnson, S. V. Kotturi, J. Org. Chem. 2001, 66, 2822.

[22] M. Jonas, S. Blechert, E. Steckhan, J. Org. Chem. 2001, 66, 6896.

[23] P. N. Collier, I. Patel, J. K. Taylor, Tetrahedron Lett. 2002, 43, 3401.

[24] S.-K. Kang, K.-Y. Jung, C.-H. Park, E.-Y. Namkoong, T.-H. Kim, Tetrahedron Lett. 2002, 36, 6287.

[25] D. Hous, F. Kerr, S. Warren, Chem. Commun. 2000, 1783.

[26] B. Ernst, J. Gonda, R. Jeschke, U. Nubbemayer, R. Oehrlein, D. Belluš, Helv. Chim. Acta 1997, 80, 876.

[27] C. E. Schwartz, D. P. Curran, J. Am. Chem. Soc. 1990, 112, 9272.

[28] P. N. Collier, A. D. Campbell, I. Patel, J. K. Taylor, Tetrahedron Lett. 2000, 41, 7115.

[29] C. R. Harris, S. D. Kuduk, A. Balog, K. Savin, P. W. Glunz, S. J. Danishefsky, J. Am. Chem. Soc. 1999, 121, 7050.

[30] S. Walbert, W. Pfleiderer, U. E. Steiner, Helv. Chim. Acta 2001, 84, 1601.

[31] H. Giegrich, S. Eisele-Bühler, C. Hermann, E. Kvasyuk, R. Charubala, W. Pfleiderer, Nucleosides Nucleotides 1998, 17, 1987.

[32] I. Sapountzis, P. Knochel, Angew. Chem., Int. Ed. 2002, 41, 1610.

[33] C. P. Gorst, P. S. Steyn, J. Chem. Soc., Perkin Trans. 1 1987, 163.

[34] H. A. Fahim, A. M. Fleifel, J. Chem. Soc. 1952, 4519.

[35] B. Neises, W. Steglich, Angew. Chem., Int. Ed. 1978, 17, 552.

[36] E. J. Corey, J.-L. Gras, P.Ulrich, Tetrahedron Lett. 1976, 809.

[37] A. G. Schultz, S. J. Kirincich, J. Org. Chem. 1996, 61, 5631.

[38] S. Kanatomo, S. Nagai, T. Hase, K. Ohki, C. Nomura, E. Okezaki, Chem. Pharm. Bull. 1983, 31, 135.

[39] S. Paul, R. R. Schmidt, Synlett 2002, 1107.

[40] D. Vadolas, H. P. Germann, S. Thakur, W. Keller, E. Heidemann, Int. J. Pept. Protein Res. 1985, 25, 554.

[41] H. Christopher, S. Smiles, J. Chem. Soc. 1911, 2046.

[42] J. C. Sheehan, J. Preston, J. Am. Chem. Soc. 1965, 87, 2492.

[43] J. C. Sheehan, S. L. Ledis, J. Am. Chem. Soc. 1973, 95, 875.

[44] S. Nozaki, I. Muramatsu, Bull. Chem. Soc. Jpn. 1982, 55, 2165. 
[45] D. Schwinn, W. Bannwarth, Helv. Chim. Acta 2002, 85, 255.

[46] D. R. Williams, M. G. Fromhold, J. D. Earley, Org. Lett. 2001, 3, 2721.

[47] S. Takaoka, K. Nakade, Y. Fukuyama, Tetrahedron Lett. 2002, 43, 6919

[48] T. Yoshida, N. Matsuura, K. Yamamoto, M. Doi, K. Shimada, T. Morie, S. Kato, Heterocycles 1996, $43,2701$.

[49] H. Gilman, J. W. Diehl, J. Org. Chem. 1959, 24, 1914. 